\title{
norden
}

\section{Højere uddannelse i Norden}

Kortlægning af eksisterende data og informationer om højere uddannelse i Norden 

4 norden 



\section{Højere uddannelse i Norden}

Kortlægning af eksisterende data og informationer om højere uddannelse i Norden

Kurt Johannessen, Epinion København

TemaNord 2013:512 
Højere uddannelse i Norden

Kortlægning af eksisterende data og informationer om højere uddannelse i Norden

Kurt Johannessen, Epinion København

ISBN 978-92-893-2480-9

http://dx.doi.org/10.6027/

TemaNord 2013:512

(C) Nordisk Ministerråd 2013

Layout: NMR

Omslagsfoto: ImageSelect

Tryk: Rosendahls-Schultz Grafisk

Oplag: 130

Printed in Denmark

Denne rapport er udgivet med finansiel støtte fra Nordisk Ministerråd. Indholdet i rapporten afspejler dog ikke nødvendigvis Nordisk Ministerråds synspunkter, meninger, holdninger eller anbefalinger.

www.norden.org/da/publikationer

\section{Det nordiske samarbejde}

Det nordiske samarbejde er en af verdens mest omfattende regionale samarbejdsformer. Samarbejdet omfatter Danmark, Finland, Island, Norge og Sverige samt Færøerne, Grønland og Åland.

Det nordiske samarbejde er både politisk, økonomisk og kulturelt forankret, og er en vigtig medspiller i det europæiske og internationale samarbejde. Det nordiske fællesskab arbejder for et stærkt Norden i et stærkt Europa.

Det nordiske samarbejde ønsker at styrke nordiske og regionale interesser og værdier i en global omverden. Fælles værdier landene imellem er med til at styrke Nordens position som en af verdens mest innovative og konkurrencedygtige regioner.

\section{Nordisk Ministerråd}

Ved Stranden 18

1061 København K

Telefon (+45) 33960200

www.norden.org 


\section{Indhold}

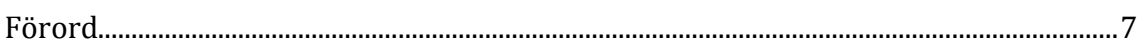

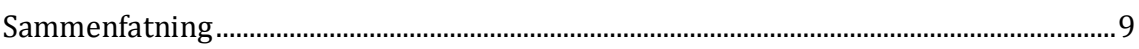

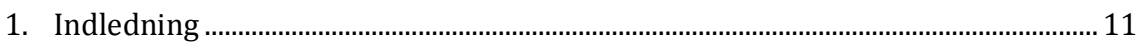

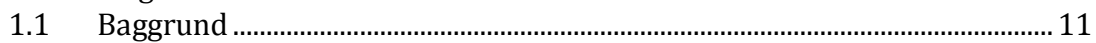

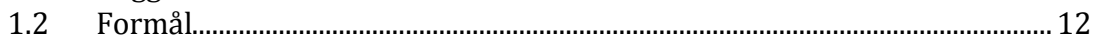

1.3 Definitioner og Bologna ....................................................................................

2. De nordiske uddannelsesniveauer ............................................................................15

3. Bestand på hovedfaggrupper ………………………………………………………….... 21

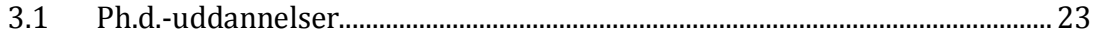

3.2 Dimensionering og akkreditering......................................................................2

3.3 Unges opfattelse af de enkelte fagområder ......................................................... 27

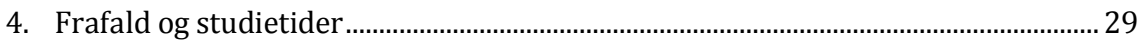

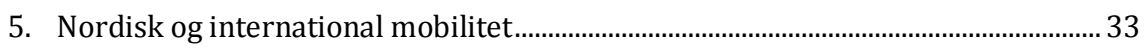

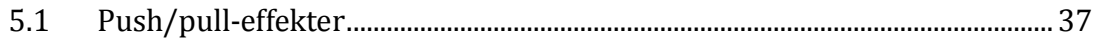

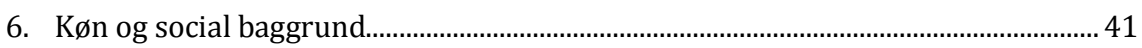

6.1 Mænd og kvinder på de højere uddannelser .................................................... 41

6.2 Kønsforskelle i uddannelsesvalg.................................................................. 43

7. Social uddannelsesmobilitet.......................................................................................... 45

7.1 Chancelighed i uddannelse ............................................................................... 47

7.2 Minoritetsbaggrund .............................................................................................. 49

8. Effekter af uddannelse ..............................................................................................

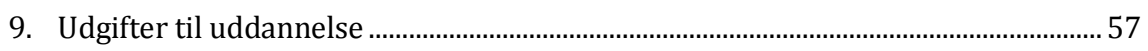

10. Fra højere uddannelse til arbejdsmarked...................................................................5

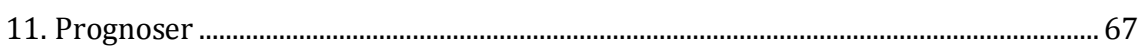

Summary of results.................................................................................................................. 71

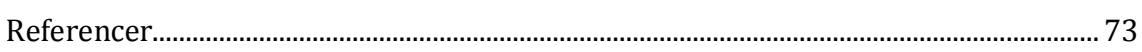





\section{Förord}

Utbildning, forskning och innovation utgör grundförutsättningar för framtida tillväxt och välstånd i Norden. I alla våra nordiska länder strävar vi efter att skapa internationellt attraktiva kunskapsmiljöer i en alltmer hårdnande global konkurrens. Vi försöker att locka hit talangfulla studerande och forskare, som kan bidra till att stärka den snabbt växande kunskapsekonomin i vår region. Vår ambition är också att öka attraktionskraften i Norden för att behålla de initiativrika och innovativa personer som redan bor här.

För att de nordiska länderna ska kunna konkurrera om att attrahera och utbilda de bästa studerande måste nordisk kvalitet och styrkepositioner inom det högre utbildningsområdet synligöras. Ett lyckat resultat kräver insatser från många olika aktörer: universitet, forskare, politiker, tjänstemän, institutioner, den privata sektorn och andra experter. Nordiska ministerrådet har som målsättning att medverka till det nordiska samarbetet inom området genom att bidra till ökad kontakt mellan nordiska läroanstalter och lyfta fram Norden som en attraktiv studiedestination. Som ett steg i detta arbete har Nordiska ministerrådet beslutat att genomföra en studie av vilka data och vilken information om högre utbildning som finns att tillgå i våra respektive länder samt hur denna information kan användas för att för att stärka Nordens konkurrenskraft inom området.

En av de nordiska ländernas stora styrkor är den bredd av avancerade datasystem och indikatorer vi använder oss av för att mäta och systematisera data om högre utbildning i våra länder. Ministerrådets uppfattning är att dessa data samordnat kan utgöra en bas för att få en fördjupad insikt och förståelse om våra system för högre utbildning. De kan även användas som underlag för benchmarking med andra länder och utnyttjas för att lyfta fram och marknadsföra våra nordiska högre utbildningsinstitutioner på den internationella arenan.

Den här rapporten har utarbetats av Epinion på uppdrag av Nordiska ministerrådet med ambitionen att utgöra ett underlag för det vidare arbetet med att profilera och synligöra det nordiska högre utbildningsområdet. Rapporten har haft som mål är att kartlägga vilka data och vilken information om högre utbildning som finns lättillgänglig i våra länder samt att lägga fram ett förslag om hur man kan samordna dessa och förmedla dem ut i Norden och internationellt. 
Min förhoppning är att rapporten ska utgöra ett värdefullt bidrag till det vidare arbetet med att synliggöra kvalitet och styrkor inom det nordiska högre utbildningsområdet.

Köpenhamn den 6 december 2012

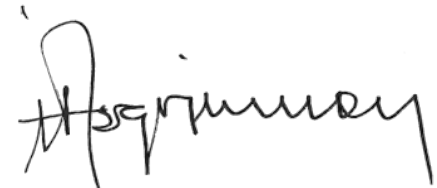

Halldór Ásgrímsson

Generalsekretær

Nordisk Ministerråd 


\section{Sammenfatning}

Rapporten bidrager til at skabe sammenlignelige uddannelsestal for de nordiske lande, hvilket forbedrer belysningen af forskelle i uddannelsesadfærd og danner basis for en Nordic Education at Glance. Endvidere udgør rapporten et væsentligt supplement til University Profile projektet (CHEPS) på en række områder som fx:

- Profiltal for årgange (participation rates), fuldførelsesprocenter og erhvervsfrekvenser.

- Sociale baggrundsfaktorer.

- Højere detaljegrad i data og fremtidsudsigter for de nordiske videregående uddannelser.

Rapporten giver anledning til at drage en række konklusioner om højere uddannelse i Norden. De vigtigste er gengivet i punktform i det følgende:

- Kandidatfrekvenser (graduation rates) i de nordiske lande er støt stigende og ligger til stadighed betydeligt over både OECD- og EUgennemsnit, selvom der er relativt betydelige forskelle mellem de nordiske lande.

- Studerende i Norden har fortsat relativt lange gennemførelsestider men dog aftagende. Nordiske fuldførelsesprocenter er generelt ikke højere end OECD- og EU-gennemsnit.

- De nordiske lande har alle et stigende optag af internationale fulldegree studerende.

- Produktionen af ph.d.ere er stigende i hele Norden, men dog svagt aftagende for Finland og især Sverige, der tidligere har været førende, mens Danmark nu har høje produktionstal.

- Kvinder i Norden er bedre end mænd til at opnå uddannelse - og i tiltagende grad. Ekspansionen på de videregående uddannelser har medført et kønsgab, hvor kvinder uddanner sig mere.

- Norden er bedre til at bryde social arv i uddannelse end EU-25 - især for mænd. Norden har inkluderende skolesystemer, hvorfor der er gode forudsætninger for at skabe uddannelsesmæssig chancelighed. I Norden er der større uddannelsesmæssig chancelighed end i EU-25; dog halter Island bagefter.

- Nyuddannede med højere uddannelse i Norden har lavere arbejdsløshedsfrekvenser end i EU - og klarer sig bedre end andre nyuddannede (ditto i EU). 
- Trods aktuel ledighed blandt højtuddannede i Norden er der udsigt til mangel på længere sigt, særligt i Norge.

- Det privatøkonomiske afkast af højere uddannelse er lavere i de nordiske lande på grund af en meget egalitær lønstruktur.

- Nordiske landes højtuddannede scorer meget højt på blødere værdier som stemmeafgivning, frivilligt arbejde og tilfredshed med livet. 


\section{Indledning}

Nærværende rapports formål er at kortlægge de højere uddannelser i Norden. En af idéerne har været at lancere en slags Nordic Education at Glance med et mere geografisk snævert fokus end den velkendte publikation Education at a Glance som OECD har udgivet hvert år siden 1993, og som er blevet referencepunkt for mange internationale uddannelsessammenligninger som fx. UNESCO's statistik. I Nordisk Statistisk Årbog er foretaget flere interessante sammenligninger, men det er oplagt at lave en nordisk version af Education at Glance. Nærværende rapport går ikke hele vejen, men indfrier en stor del af ambitionen.

Som i forbilledet mangler vi indimellem uddybende forklaringer på forskellene i de opnåede outputs inden for hver af de opstillede indikatorer. Nogen gange er det let at fortolke forskelle mellem Nordeuropa og Sydeuropa og mellem Europa og Nordamerika. Men det kan være sværere at fortolke forskelle mellem de nordiske lande. Vi har jo i den grad en fælles historie og en fælles opfattelse af uddannelsens rolle i samfundet. Men der er også betydelige forskelle, hvor nogen kan skyldes forskellig metode og terminologi, mens andre kan skyldes reelle adfærdsforskelle. Med nærværende rapport er håbet, at ambitionen om en Nordic Education at Glance kan stimulere til endnu flere dybtgående undersøgelser af nordisk uddannelsesadfærd.

\subsection{Baggrund}

En profilering og synliggørelse af Norden som en attraktiv uddannelsesregion hører ind under Nordisk Ministerråds globaliseringsprojekt om "Fremme af højere uddannelse i Norden." For at Norden skal kunne konkurrere om at tiltrække og uddanne de bedste studerende, må nordisk kvalitet og styrkepositioner i højere uddannelsesinstitutioner fremhæves og markedsføres.

Baggrunden for Nordisk Ministerråds ønske om at få kortlagt eksisterende data og informationer om højere uddannelse i Norden skal ses i lyset af et ønske om nordisk nytte. Det betyder, at aktiviteter gennemført inden for det nordiske samarbejdes rammer - gennem fælles nordiske indsatser og løsninger - skal medføre: 
- Dokumenterbare synergieffekter vurderet i forhold til en isoleret national indsats.

- Manifestere og udvikle nordisk samhørighed.

- Øge nordisk kompetence.

- Øge nordisk konkurrenceevne.

Et stærkere og mere attraktivt fællesnordisk marked for højere uddannelse rummer potentialerne for både synergieffekter, stærkere nordisk samhørighed, øgede nordiske kompetencer gennem udveksling samt øget nordisk konkurrenceevne som følge af tiltrækning og uddannelse af de bedste studerende.

De nordiske lande udmærker sig ved at have rimelig fintmaskede datasystemer og udtømmende indikatorer, som leverer brugbar og gennemsigtig information om højere uddannelse. Dette kan udgøre et solidt grundlag for benchmarking med andre lande og bør af samme grund bruges offensivt i profileringen af nordiske højere uddannelsesinstitutioner.

\subsection{Formål}

I forbindelse med kortlægningen af eksisterende data og informationer om højere uddannelse i Norden er der jf. opdragsmaterialet to overordnede udfordringer, som skal adresseres:

1. At kortlægge eksisterende og lettilgængelige data og information omkring forskellige aspekter af højere uddannelse på landeniveau. Eksempelvis:

- Optagelse og søgning til højere uddannelsesinstitutioner.

- Tilgang, bestand og fuldførelse ved bachelor-, kandidat-/master- og ph.d.

- Ph.d. produktion.

- De studerendes profil, herunder alder, køn etc.

- De studerendes sociale baggrund og forhold, herunder levevilkår og minoritetsbaggrund.

- Frafald ved bachelor- og kandidatuddannelser.

- International mobilitet, herunder antallet af ind- og udgående studerende.

- Efteruddannelse på højere uddannelsesinstitutioner.

- Højere uddannelsesinstitutioners videnskabelige personale, antal af medarbejdere.

- Nyuddannedes beskæftigelse og ledighed.

- Arbejdsmarkedstilknytning. 
2. At fremsætte forslag til, hvordan man bedst samordner disse data, og formidler dem ud i Norden og internationalt.

- Med henblik på at promovere og kommunikere nordisk kvalitet og styrkepositioner til interessenter ville det på baggrund af kortlægningen fx.være en mulighed at udvikle en lettilgængelig og brugervenlig vidensportal.

I rapporten inddrages yderligere følgende forhold:

- At foretage komparationer med andre ikke-nordiske lande således, at særlige nordiske karakteristika træder tydeligere frem.

- At afsøge den eksisterende viden om, hvilke push/pull-faktorer, der er afgørende for, at ikke-nordiske studerende tager til Norden samt, at nordiske studerende bliver i Norden.

- At inddrage prognostisk viden om fremtidens uddannelse og arbejdsmarked.

Begrebsapparatet i rapporten knytter sig først og fremmest til statistiske indikatorer i EAG og nationale nordiske terminologer. Men der er alligevel mulighed for at sammenholde analyserne med resultater fra Umapping-projektet mv.

\subsection{Definitioner og Bologna}

Historisk har der været forskellige definitioner af højere uddannelse i Norden jf. tabel 1.1 .

Tabel 1.1: Traditionelle, nationale definitioner af højere uddannede

\begin{tabular}{|c|c|c|c|c|c|}
\hline Land & Danmark & Norge & Sverige & Island & Finland \\
\hline Niveau & $\begin{array}{l}\text { Prof bachelor/Lang } \\
\text { videregående } \\
\text { uddannelse. }\end{array}$ & $\begin{array}{l}\text { Videregåen- } \\
\text { de uddannel- } \\
\text { se, mere end } \\
4 \text { år. }\end{array}$ & $\begin{array}{l}\text { Videregående } \\
\text { uddannelse, } 3 \\
\text { år eller mere }\end{array}$ & ISCED $5+6$ & $\begin{array}{l}\text { Lang videregående } \\
\text { uddannelse }\end{array}$ \\
\hline $\begin{array}{l}\text { Beskri- } \\
\text { velse }\end{array}$ & $\begin{array}{l}\text { En uddannelse af } \\
\text { mindst } 31 \frac{1}{2} \text { å } \\
\text { varighed på kandi- } \\
\text { datniveau. } \\
\text { Forskeruddannelse } \\
\text { har særskilt kategori. }\end{array}$ & $\begin{array}{l}\text { En uddannel- } \\
\text { se på kandi- } \\
\text { datniveau } \\
\text { (niveau 7) } \\
\text { eller forsker- } \\
\text { uddannelse } \\
\text { (niveau 8). }\end{array}$ & $\begin{array}{l}\text { Alle uddannelse } \\
\text { med en længde } \\
\text { over } 3 \text { år } \\
\text { klassificeres i } \\
\text { samme katego- } \\
\text { ri. }\end{array}$ & $\begin{array}{l}\text { Island } \\
\text { anvender } \\
\text { ISCED- } \\
\text { klassifika- } \\
\text { tion. }\end{array}$ & $\begin{array}{l}\text { En uddannelse af 5- } \\
6 \text { års varighed på } \\
\text { kandidatniveau. } \\
\text { Forskeruddannelse } \\
\text { har særskilt kategori. }\end{array}$ \\
\hline
\end{tabular}


De traditionelle definitioner er nu erstattet af ISCED-klassifikation jf. tabel 1.2 .

Tabel 1.2: ISCED-klassifikation

\begin{tabular}{ll}
\hline & Beskrivelse \\
\hline ISCED 5B & $\begin{array}{l}\text { Videregående uddannelser, som er praktiske/tekniske/erhvervsspecifikke. } \\
\text { Videregående uddannelser, som enten er teoretisk baseret/forskning forberedende (historie, } \\
\text { filosofi, matematik, osv.) eller giver adgang til erhverv med høje kvalifikationskrav (f.eks. } \\
\text { medicin, tandlæge, arkitektur, osv.). }\end{array}$ \\
ISCED 6 & Forskeruddannelser (ph.d.)
\end{tabular}

Bologna-processen er et uddannelsespolitisk samarbejdet, som har til formål, at udvikle et fælles område for videregående uddannelse, hvor de studerende frit kan bevæge sig over grænserne. Man ønsker derigennem bl.a. at styrke studentermobiliteten. En central del af Bolognaprocessen handler om at harmonisere gradsstrukturen for højere uddannelser, og dermed fjerne grænsehindringer, øge gennemsigtigheden og øge konkurrenceevnen af de europæiske uddannelser og universitetet. Man har indført en fælles meritsystem, som er baseret på ECTS, og inddelt højere uddannelser i to niveauer, bachelorer og master uddannelser. I Bologna-deklarationen fra 1999 og efterfølgende kommunikéer udtrykker undervisningsministrene en fælles vilje til at arbejde for 10 hovedmålsætninger:

1. Udvikling af letlæselige og sammenlignelige uddannelser og uddannelsesbeviser, bl.a. gennem anvendelse af Diploma Supplement.

2. Udvikling af en gradsstruktur der omfatter to niveauer ( $3+2$ år).

3. Udvikling af et meritsystem baseret på ECTS der fremmer studentermobiliteten.

4. Fjernelse af mobilitetshindringer for såvel studerende som lærere.

5. Samarbejde om udvikling af kvalitetssikring.

6. Styrkelse af den europæiske dimension i uddannelserne.

7. Livslang uddannelse.

8. Inddragelse af institutioner og studerende i processen.

9. Styrkelse af de europæiske højere uddannelsers tiltrækningskraft og konkurrenceevne.

10.Forskeruddannelse og øget synergi mellem forskning og uddannelse i det europæiske samarbejde. 


\section{De nordiske uddannelsesniveauer}

De nordiske landes uddannelsesniveau er betydeligt højere end OECD og EU-gennemsnittet. Hele den voksne befolknings uddannelsesniveau er vokset betydeligt også efter år 2000. Blandt de 25-34 årige er de øverst placerede lande Norge og Danmark ved at nærme sig en andel på 45 pct.

Figur 2.1: Andel med videregående uddannelse 25-34 årige (2001-2009), Eurostat

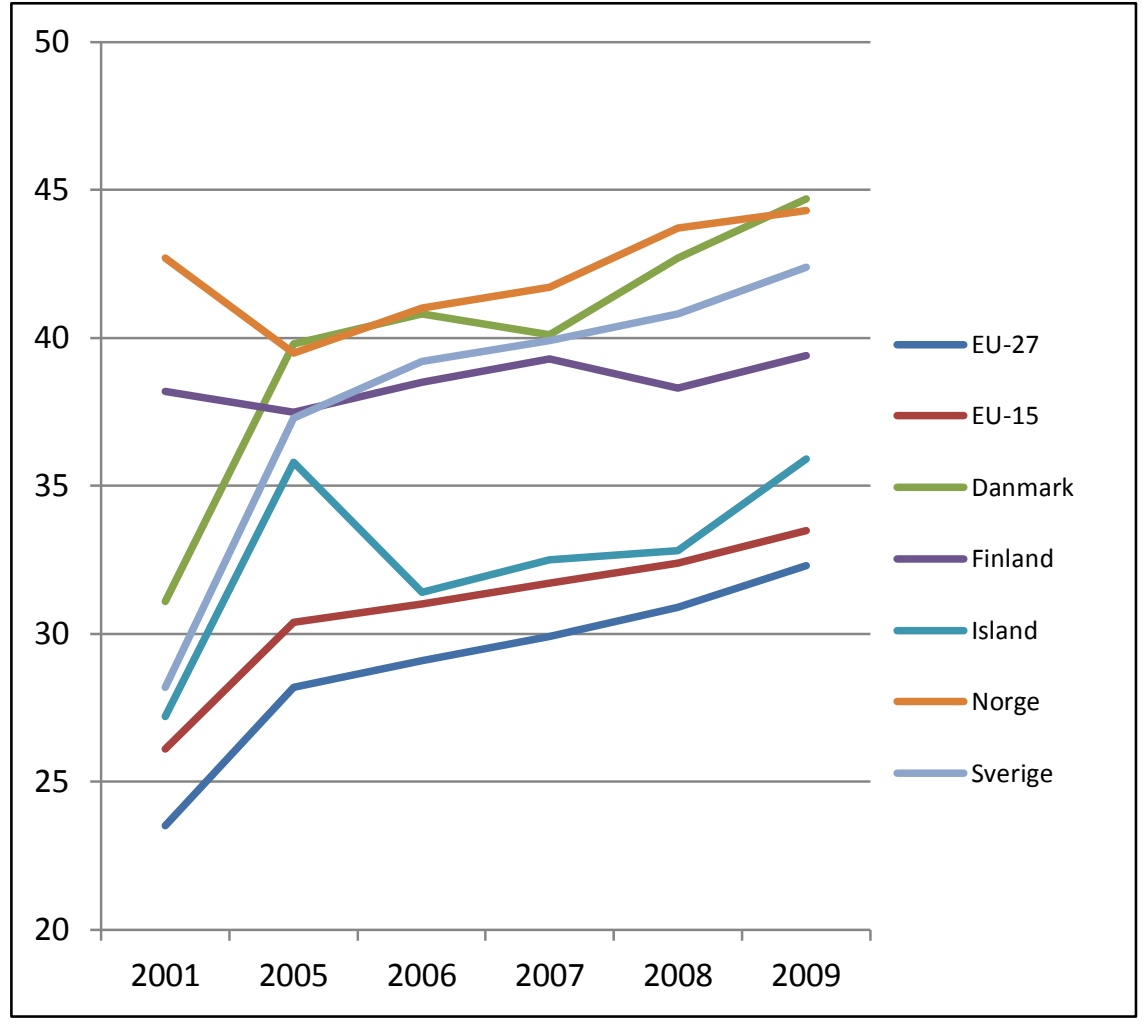

Ser man på optagelsesfrekvenserne til højere uddannelser på ISCED 5A niveau, er disse efterhånden meget høje. Kun Danmark ligger under OECD- og EU-gennemsnit. Til gengæld ligger Danmark som det eneste nordiske land med en ret høj ISCED 5A frekvens. Forskellen mellem tabellerne ligger i frafaldet. 
Tabel 2.1: Optagelsesandele til tertiær uddannelse set I forhold til relevant ungdomsårgang

\begin{tabular}{lccccccc} 
& $\mathbf{1 9 9 5}$ & $\mathbf{2 0 0 0}$ & $\mathbf{2 0 0 5}$ & $\mathbf{2 0 0 6}$ & $\mathbf{2 0 0 7}$ & $\mathbf{2 0 0 8}$ & $\mathbf{2 0 0 9}$ \\
\hline Danmark & 40 & 52 & 57 & 59 & 57 & 59 & 55 \\
Finland & 39 & 71 & 73 & 76 & 71 & 70 & 69 \\
Island & 38 & 66 & 74 & 78 & 73 & 73 & 77 \\
Norge & 59 & 67 & 73 & 70 & 70 & 71 & 77 \\
Sverige & 57 & 67 & 76 & 76 & 73 & 65 & 68 \\
OECD & 37 & 47 & 54 & 55 & 55 & 56 & 59 \\
EU-21 & 35 & 46 & 53 & 54 & 54 & 54 & 58 \\
\hline
\end{tabular}

Kilde: Education at a Glance 2011, Tabel C2.2.

Sverige og Norge havde i 1995 særligt høje optagelsesandele, men de øvrige nordiske lande ligger tættere på OECD- og EU gennemsnit. Island og Finland voksede meget stærkt frem til 2009. 
Tabel 2.2: Kandidatuddannelsesfrekvens 2010

\begin{tabular}{|c|c|c|c|c|c|c|c|c|}
\hline & \multicolumn{2}{|c|}{ Tertiary-type A (first time) } & \multicolumn{2}{|c|}{ Tertiary-type A (First degree) } & \multicolumn{2}{|c|}{ Tertiary-type A (second degree) } & \multicolumn{2}{|c|}{ Advanced research programme } \\
\hline & Alle studerende & $\begin{array}{r}\text { Justeret- } \\
\text { kandidatuddannelsesfrekvens }\end{array}$ & Alle studerende & $\begin{array}{l}\text { Justeret genem- } \\
\text { førelsesprocent }\end{array}$ & Alle studerende & $\begin{array}{r}\text { Justeret genemførel- } \\
\text { sesprocent }\end{array}$ & Alle studerende & $\begin{array}{r}\text { Justeret gennem- } \\
\text { førelsesprocent }\end{array}$ \\
\hline Danmark & 50 & 46 & 49 & 47 & 20 & 18 & 2,0 & 1,7 \\
\hline Finland & 49 & - & 46 & 45 & 24 & 23 & 2,3 & 2,2 \\
\hline Island & 60 & 57 & 63 & 62 & 24 & 22 & 0,8 & 0,6 \\
\hline Norge & 42 & 41 & 46 & 45 & 12 & 11 & 1,8 & 1,6 \\
\hline Sverige & 37 & 32 & 35 & 34 & 8 & 4 & 2,8 & 2,2 \\
\hline OECD & 39 & - & 38 & - & 15 & - & 1,6 & - \\
\hline EU-21 & 40 & - & 37 & - & 17 & - & 1,7 & - \\
\hline
\end{tabular}

Kilde: Education at a Glance 2012, Tabel A3.3 Adjusted graduation rate har medregnet nettoeffekten af nordiske kandidater, der tager en kandidatuddannelse uden for landets grænser og internationale kandidaters eksaminer i nordiske lande. 
Uddannelsesfrekvensen på tertiært niveau har Island i en topplacering for first time kandidater med over 50 pct. Sverige ligger på denne indikator lavere end OECD- og EU-21 gennemsnittene. De videregående fuldførelsesniveauer er vokset kraftigt i de sidste 15 år.

Figur 2.2: Udviklingen i tertiær fuldførelsesniveau (1995-2009)

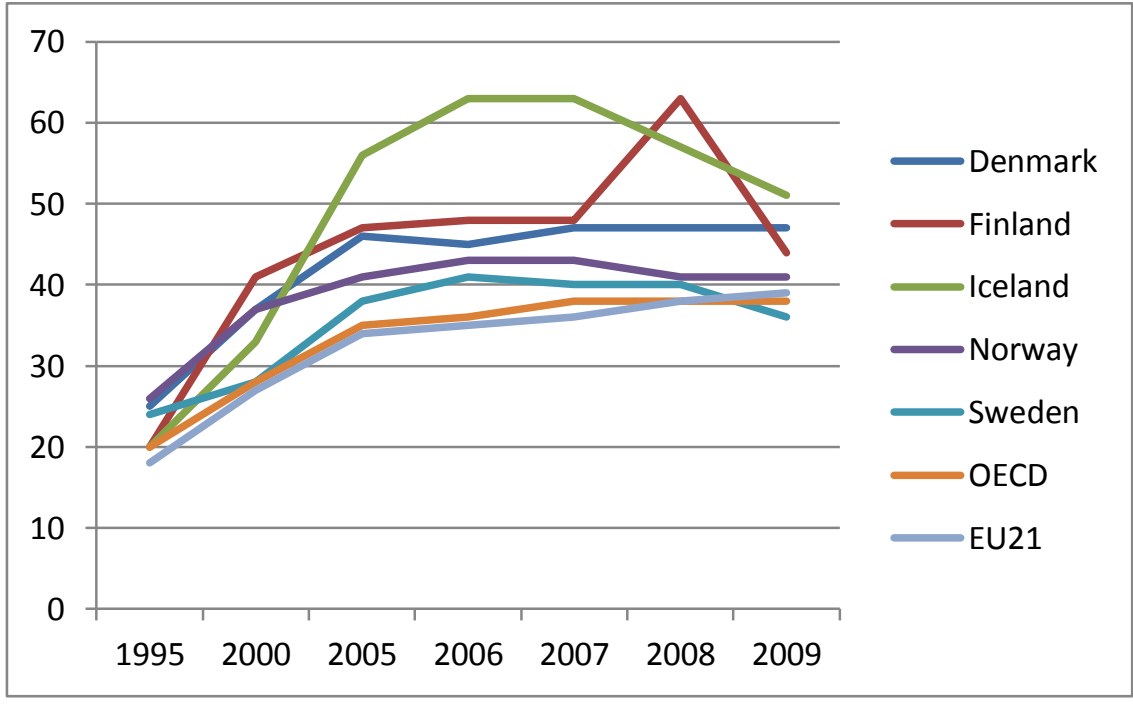

Kilde: Education at a Glance 2011.

Figur 2.3: Fuldførelsesfrekvenser på videregående niveau

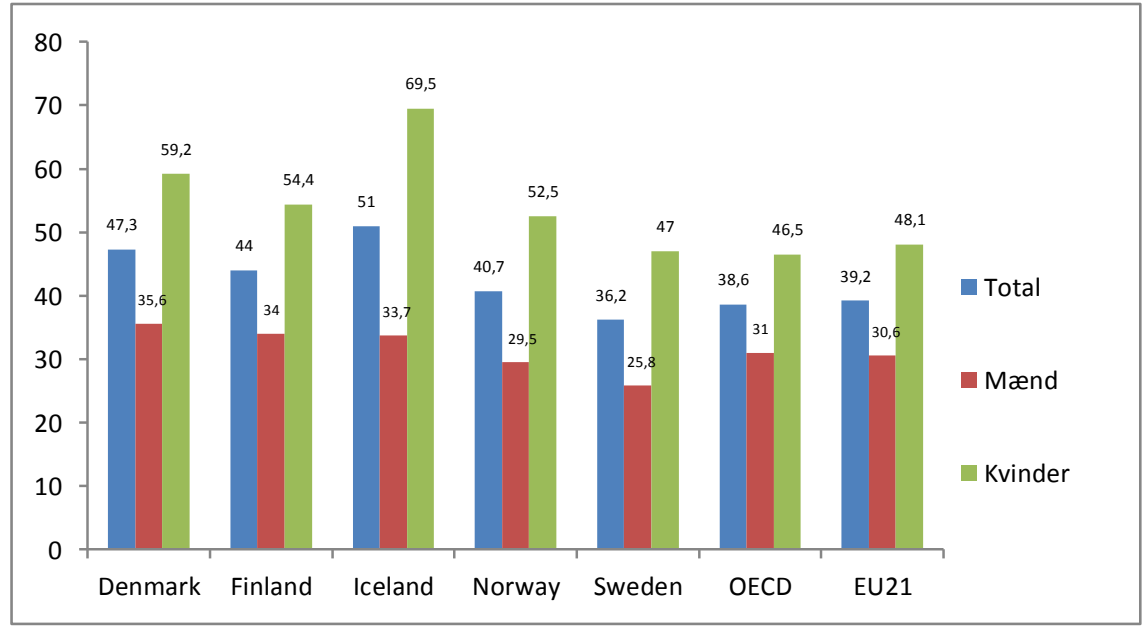

Kilde: Education at a Glance 2011. 
Figuren ovenfor viser overraskende store forskelle mellem de nordiske lande og store kønsforskelle. Sverige ligger på denne variabel under OECDgennemsnittet. Særligt Island og Norge ligger meget højt. Kønsforskellene er ret markante. På Island er deltalgelsesfrekvensen dobbelt så høj for kvinder som for mænd. Nedenstående figur viser på en lidt anden måde uddannelsesniveauet, også kønsopdelt. Forskellene mellem de nordiske lande er her mindre og afstanden til OECD-gennemsnittet større.

Figur 2.4: Andel med videregående uddannelse 25-34 år (2009)

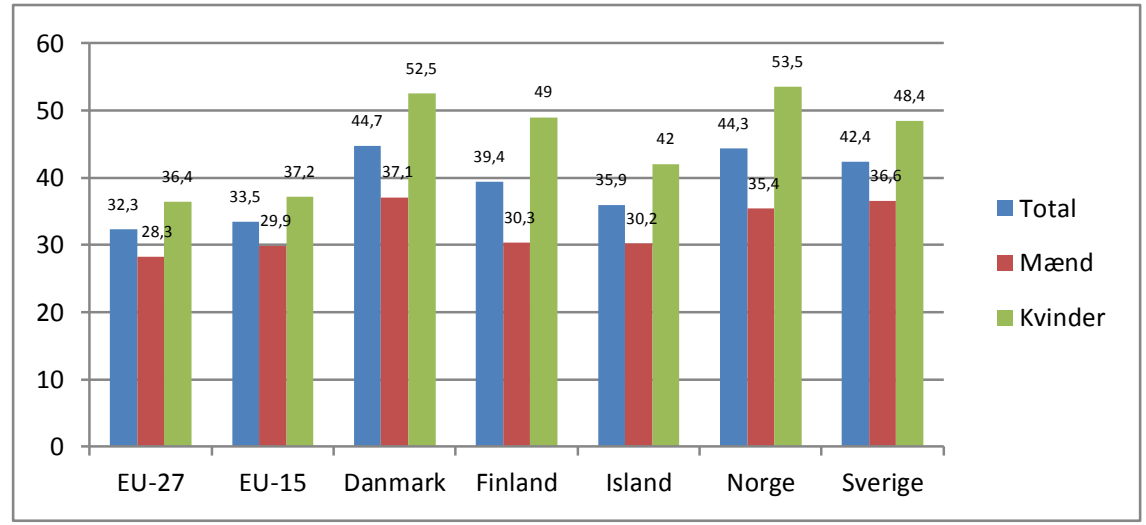

Der er i de nordiske lande en høj overgang fra bachelor- til kandidatniveau. På visse uddannelser er den op imod 90 pct.

Overgangene mellem kandidatniveau og ph.d.-niveau i de enkelte nordiske lande ligger på mellem 5 og 25 pct. af kandidatårgangen. Der er meget store forskelle på de enkelte fagområder med teknisk og naturvidenskab på et overgangsniveau på over 25 pct. og humaniora og samfundsvidenskab på et niveau ofte under 5 pct. En sammenstilling af hvert hovedområde for alle de nordiske lande giver værdifuld viden.

I OECD måler man fx. ph.d.-produktionen som andel af en relevant ungdomsårgang som afslutter en ph.d. Vi er her stadig nede på et nordisk niveau, som ikke er højere end at par pct. Beregningen af overgang fra kandidatniveau til ph.d.-niveau er ikke uden kompleksitet på grund af venteperioder både før og under ph.d.-studiet.

Ovenstående analyse baserer sig på OECD-statistik mv. Nedenstående danske case illustrerer på en lidt anden måde den kraftige udvikling vi har set. Det er en kraftig udvikling, man ser. Alene de lange videregående uddannelser på Masters niveau er vokset fra 11,0 pct. af en ungdomsårgang til næsten 24 pct. I alt er de videregående uddannelser vokset fra ca. 35 pct. til næsten 54 pct.

Udviklingen har været tilsvarende kraftig i alle nordiske lande, men uden en integreret elevstatistik på individniveau lader helt samme beregning sig ikke udføre. 
Tabel 2.4: Udvikling i uddannelsesniveau siden 1990. Et dansk case. Pct.

\begin{tabular}{lrrrrr}
\hline Erhvervskompetencegivende uddannelser & $\mathbf{1 9 9 0}$ & $\mathbf{1 9 9 5}$ & $\mathbf{2 0 0 0}$ & $\mathbf{2 0 0 5}$ & $\mathbf{2 0 1 0}$ \\
\hline Merkantil erhvervsfaglig uddannelse & 16,6 & 12,3 & 10,4 & 8,3 & 7,1 \\
Teknisk erhvervsfaglig uddannelse & 15,9 & 15,8 & 18,3 & 16,1 & 13,3 \\
SOSU mv. erhvervsfaglig uddannelse & 3,2 & 6,4 & 6,7 & 6,9 & 6,5 \\
Kort videregå ende uddannelse & 5,3 & 7,8 & 8,8 & 6,7 & 5,3 \\
Mellemlang videregående uddannelse & 18,4 & 23,6 & 22,7 & 23,9 & 24,5 \\
Lang videregående uddannelse & 11,0 & 11,2 & 13,9 & 17,4 & 23,8 \\
Uden kompetence & 20,3 & 14,2 & 12,3 & 13,4 & 10,4 \\
Med studiekompetence & 9,3 & 8,7 & 6,9 & 7,3 & 7,5 \\
Erhvervsfaglig uddannelse & 35,8 & 34,5 & 35,3 & 31,3 & 26,9 \\
Videregående uddannelse & 34,6 & 42,6 & 45,5 & 48,0 & 53,6 \\
Med erhvervskompetence & 70,4 & 77,1 & 80,8 & 79,3 & 80,5 \\
\hline
\end{tabular}




\section{Bestand på hovedfaggrupper}

Mens en opdeling på uddannelsesniveauer er vigtig, er opdelingen på hovedfaggrupper også yderst relevant. Satser de nordiske lande på teknik/naturvidenskab, sundhed, humaniora/pædagogik eller samfundsvidenskab - og er der forskelle mellem Norden og det øvrige OECD-område?

I tabel 3.1 ses hvorledes de nye studerende på videregående uddannelser fordeler sig på hovedområder. Hvis man sammenligner de nordiske gennemsnit med OECD og EU-21 er det ikke så markante forskelle, der træder frem. Den største forskel skal findes på sundhedsvidenskaberne, hvor Norden ligger med en lidt højere andel på 16 pct., særligt pga. høje andele i Danmark, Finland og Norge med hhv. 19, 20 og 18 pct. Sverige ligger med en andel på 14 pct. på samme niveau som OECD og EU-21. På Island udgør Sundhed en ret lille andel med blot 9 pct. De samfundsvidenskabelige fag som jura, politologi og økonomi udgør i Norden knap en tredjedel, hvilket er marginalt lavere end OECD og EU-21.

I Danmark er andelen helt oppe på cirka 40 pct., hvor det i de andre lande ligger på omkring en tredjedel. Finland ligger noget lavere på samfundsvidenskab, hvor denne hovedfaggruppe kun udgør 21,9 pct. Til gengæld fylder ingeniørfagene meget i Finland, hvor en fjerdedel af de nye studerende starter. Naturvidenskabelige fag udgør for alle landene godt 9 pct. Ift. hvor meget humaniora udgør, er der ret markante forskelle i Norden. I Danmark og Finland udgør området cirka 15 pct. I Norge og Sverige er det knap 25 pct. og i Island er det hele 29 pct.

En af mange forklaringer på forskellige studievalg er de enkelte landes erhvervsstruktur. Island har en mindre andel der er beskæftiget inden for fremstillingserhverv f.eks. sammenlignet med Sverige, der har mange store industrivirksomheder. Der er derfor brug for flere typer ingeniører i Sverige. Island har ikke så mange videregående uddannede i den primære private sektor, og de humanistisk uddannede fylder mere med mange ansat $i$ undervisning og kulturelle institutioner. 
Tabel 3.1: Fordeling af nye studerende på videregående uddannelser, ift. hovedfaggrupper 2009

\begin{tabular}{lrrrrrrrr}
\hline & $\begin{array}{r}\text { Hum., } \\
\text { kunst mv. }\end{array}$ & Sundhed & $\begin{array}{r}\text { Samfunds- } \\
\text { videnskab }\end{array}$ & Teknik & $\begin{array}{r}\text { Natur- } \\
\text { videnskab }\end{array}$ & Jordbrug & $\begin{array}{c}\text { Ukendt eller } \\
\text { uspecificeret }\end{array}$ & Services \\
\hline Danmark & 15,5 & 19,4 & 39,2 & 12,0 & 9,1 & 2,3 & $\mathrm{n}$ & 2,5 \\
Finland & 14,9 & 20,1 & 21,9 & 24,3 & 9,1 & 2,5 & $\mathrm{n}$ & 7,2 \\
Island & 29,2 & 9,3 & 36,4 & 13,3 & 9,6 & 0,6 & $\mathrm{n}$ & 1,6 \\
Norge & 23,1 & 17,5 & 30,9 & 8,1 & 9,0 & 0,9 & 3,8 & 6,6 \\
Sverige & 24,7 & 13,9 & 28,2 & 18,5 & 9,8 & 1,1 & 0,2 & 3,5 \\
Norden gnsn. & 21,5 & 16,0 & 31,3 & 15,2 & 9,3 & 1,5 & 0,8 & 4,3 \\
OECD & 20,1 & 13,5 & 32,7 & 15,0 & 9,2 & 1,8 & 1,9 & 5,8 \\
EU-21 & 18,6 & 13,8 & 32,5 & 15,8 & 9,4 & 1,9 & 2,2 & 5,8 \\
\hline
\end{tabular}

Kilde: Education at a Glance 2011 s. 83, Tabel A4.2a.

Figur 3.1-3.6 viser grafisk de nye studerendes fordelinger på hovedfag på videregående uddannelser 2009. Nogle af områderne er lagt sammen af hensyn til overskueligheden.

Figur 3.1: Fordeling af nye studerendes på videregående uddannelser, ift. hovedfaggrupper 2009

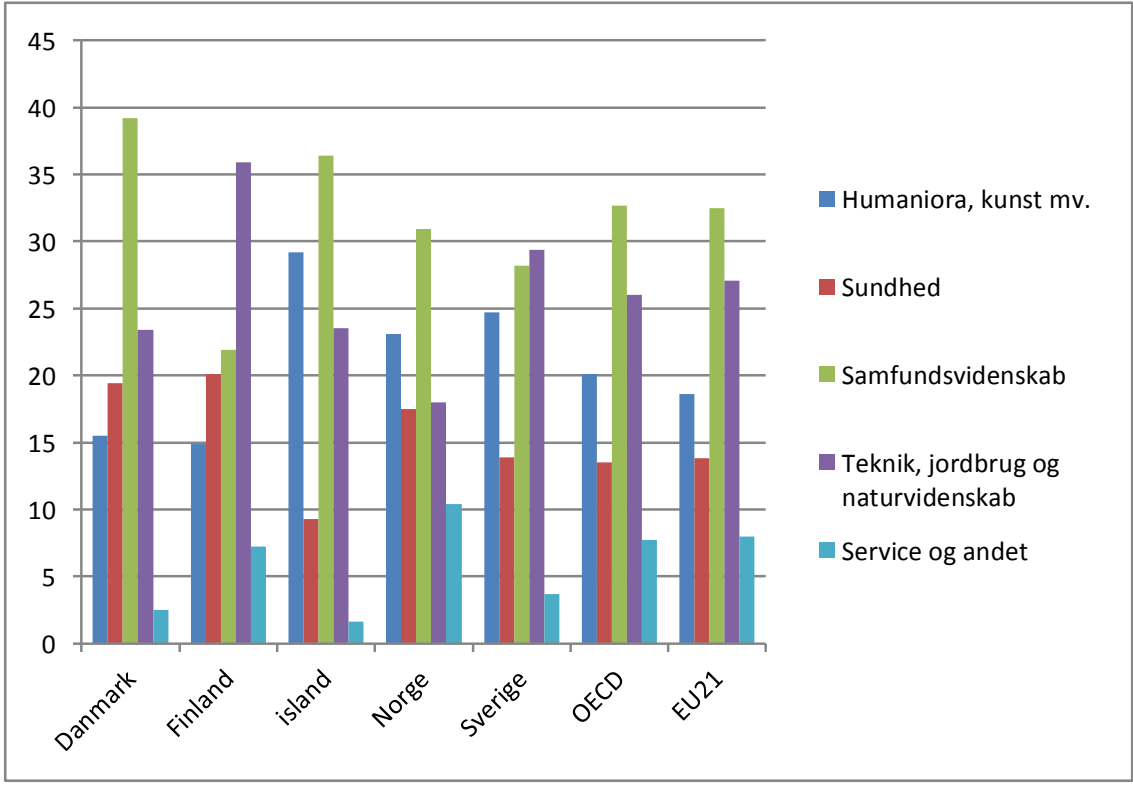

Kilde: Education at a Glance 2011 s. 83

Tabel 3.2: Danmark. Bestand af studerende på højere uddannelsesinstitutioner - fordelt på hovedområde

\begin{tabular}{lrrrrrr}
\hline & $\mathbf{2 0 0 0}$ & $\mathbf{2 0 0 3}$ & $\mathbf{2 0 0 5}$ & $\mathbf{2 0 0 7}$ & $\mathbf{2 0 0 9}$ & $\mathbf{2 0 1 0}$ \\
\hline Humaniora mv & 28 & 27 & 28 & 28 & 28 & 27 \\
Samfundsvidenskab & 26 & 26 & 26 & 28 & 28 & 29 \\
Teknik, jordbrug og naturviden- & 22 & 21 & 22 & 21 & 21 & 22 \\
skab & & & & & & \\
Sundhed & 24 & 25 & 25 & 24 & 24 & 24 \\
I alt & 100 & 100 & 100 & 100 & 100 & 100 \\
Indeks & 100 & 104 & 107 & 107 & 108 & 108 \\
Antal & 189,939 & 197,489 & 203,790 & 203,077 & 204,568 & 204,365 \\
\hline
\end{tabular}

Kilde: Eurostat. 
Tabel 3.3: Finland. Bestand af studerende på højere uddannelsesinstitutioner - fordelt på hovedområde

\begin{tabular}{lrrrrr}
\hline & $\mathbf{2 0 0 0}$ & $\mathbf{2 0 0 3}$ & $\mathbf{2 0 0 5}$ & $\mathbf{2 0 0 7}$ & $\mathbf{2 0 0 9}$ \\
\hline Humaniora mv & 20 & 20 & 20 & 20 & 19 \\
Samfundsvidenskab & 27 & 26 & 27 & 28 & 28 \\
Teknik, jordbrug og naturvidenskab & 39 & 41 & 39 & 38 & 37 \\
Sundhed & 14 & 13 & 13 & 14 & 16 \\
I alt & 100 & 100 & 100 & 100 & 100 \\
Indeks & 100 & 108 & 111 & 111 & 109 \\
Antal & 279,145 & 300,259 & 309,312 & 310,063 & 304,020 \\
\hline
\end{tabular}

Kilde: Eurostat.

Tabel 3.4: Island. Bestand af studerende på højere uddannelsesinstitutioner - fordelt på hovedområde

\begin{tabular}{lrrrrrr}
\hline & $\mathbf{2 0 0 0}$ & $\mathbf{2 0 0 3}$ & $\mathbf{2 0 0 5}$ & $\mathbf{2 0 0 7}$ & $\mathbf{2 0 0 9}$ & $\mathbf{2 0 1 0}$ \\
\hline Humaniora mv & 31 & 34 & 33 & 31 & 31 & 30 \\
Samfundsvidenskab & 36 & 37 & 39 & 40 & 39 & 38 \\
Teknik, jordbrug og naturvidenskab & 20 & 17 & 16 & 18 & 18 & 19 \\
Sundhed & 14 & 12 & 12 & 13 & 13 & 13 \\
I alt & 100 & 100 & 100 & 100 & 100 & 100 \\
Indeks & 100 & 146 & 155 & 164 & 177 & 185 \\
Antal & 10,182 & 14,896 & 15,756 & 16,651 & 18,047 & 18,865 \\
\hline
\end{tabular}

Kilde: Eurostat.

Tabel 3.5: Norge. Bestand af studerende på højere uddannelsesinstitutioner - fordelt på hovedområde

\begin{tabular}{lrrrrr} 
& $\mathbf{2 0 0 0}$ & $\mathbf{2 0 0 3}$ & $\mathbf{2 0 0 5}$ & $\mathbf{2 0 0 7}$ & $\mathbf{2 0 0 9}$ \\
\hline Humaniora mv & 29 & 27 & 27 & 27 & 26 \\
Samfundsvidenskab & 32 & 37 & 38 & 37 & 37 \\
Teknik, jordbrug og naturvidenskab & 21 & 17 & 16 & 16 & 17 \\
Sundhed & 18 & 19 & 19 & 20 & 20 \\
I alt & 100 & 100 & 100 & 100 & 100 \\
Indeks & 100 & 113 & 113 & 111 & 119 \\
Antal & 185,352 & 209,446 & 209,642 & 206,429 & 221,099 \\
\hline
\end{tabular}

Kilde: Eurostat.

Tabel 3.6: Sverige. Bestand af studerende på højere uddannelsesinstitutioner - fordelt på hovedområde

\begin{tabular}{lrrrr} 
& $\mathbf{2 0 0 0}$ & $\mathbf{2 0 0 3}$ & $\mathbf{2 0 0 5}$ & $\mathbf{2 0 0 7}$ \\
\hline Humaniora mv & 26 & 28 & 28 & 27 \\
Samfundsvidenskab & 28 & 28 & 28 & 28 \\
Teknik, jordbrug og naturvidenskab & 31 & 28 & 27 & 26 \\
Sundhed & 16 & 16 & 17 & 18 \\
I alt & 101 & 100 & 100 & 100 \\
Indeks & 100 & 120 & 118 & 117 \\
Antal & 357,934 & 429,486 & 422,460 & 418,800 \\
\hline
\end{tabular}

Kilde: Eurostat.

\subsection{Ph.d.-uddannelser}

Vi skal også dvæle kort ved ph.d.-uddannelser jf. figur 3.2 og 3.3. Produktionen af ph.d.er er stigende i Norden som helhed, men dog svagt aftagende for Finland og Sverige, der tidligere har været førende, mens Danmark nu har høje produktionstal efter at optaget på tek/nat/sund områderne er blevet fordoblet på få år. 
Figur 3.2. Bestand af ph.d.-studerende i Norden. Antal pr. mio. indbyggere. 2000-10

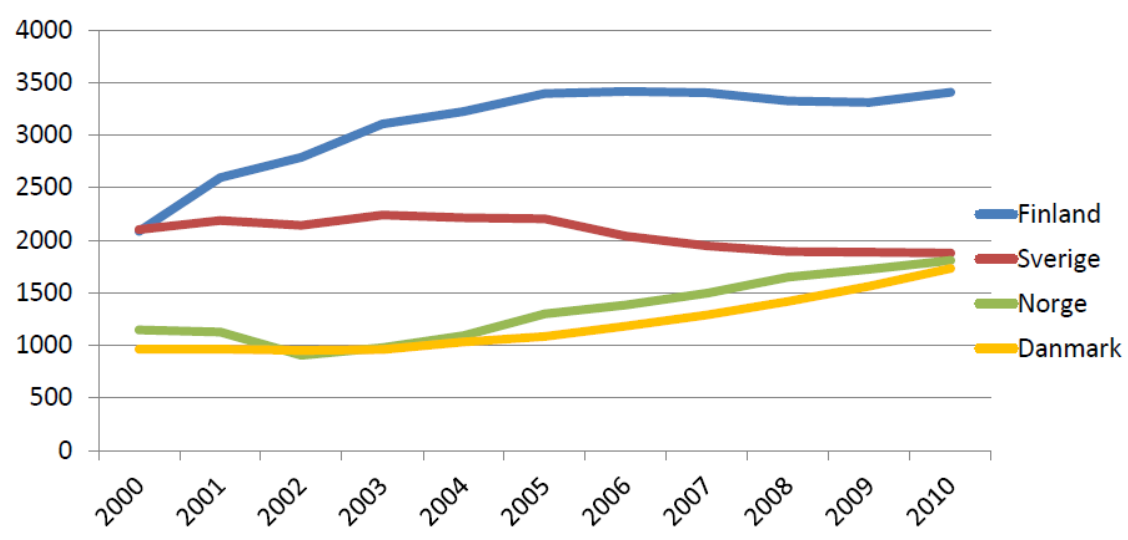

Figur 3.3. Antal ph.d.-grader pr. mio. indbyggere i Norden. 1990-2010

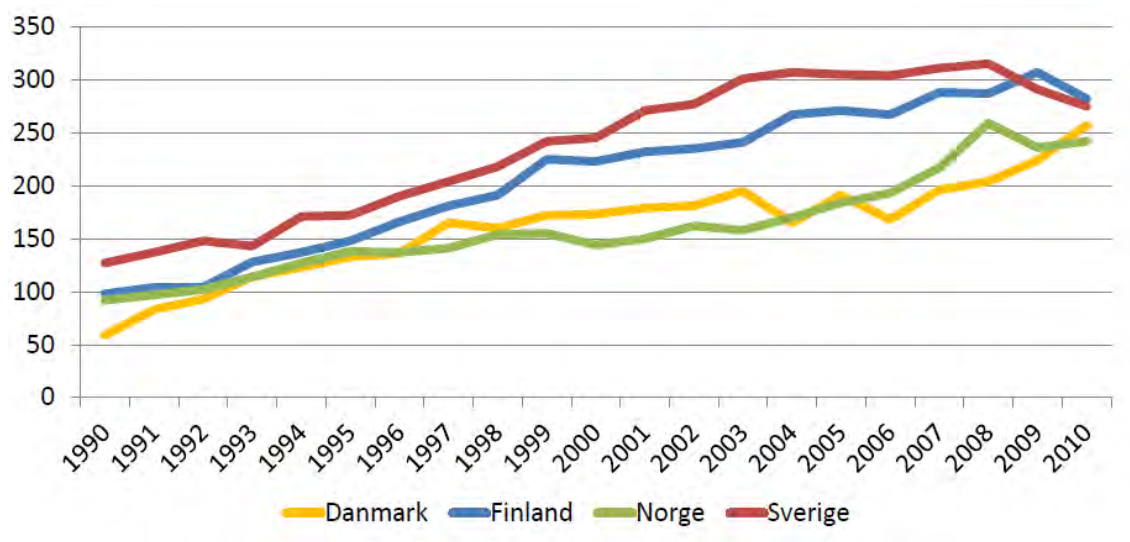




\subsection{Dimensionering og akkreditering}

Søgningsadfærden er præget af både strukturelle og konjunkturprægede forhold. Oftest skal man i de nordiske lande finde søgnings- og optagelsesstatistik i forskellige kilder.

Forskellen på søgning og optag er i princippet lig med de afviste, men statistikken kompliceres af en række bevægelser både mellem tidspunktet for søgning og optag og de mange skift der finder sted efter optagelsen. Det tidlige frafald er ofte meget stort og dækker både over studerende, som aldrig kommer i gang og studerende som aldrig møder op på det først tildelte studium, men skifter til et andet. Også efter studiestart er der en række tidlige studieskift.

Dimensionering finder man på forskellige niveauer i de nordiske lande. Generelt er der friere adgang end i mange andre OECD-lande (dog mere restriktiv end fx. i Tyskland). Dimensioneringen er hvert år en politisk beslutning. I stigende grad er den decentraliseret til de enkelte universiteter. Akkrediteringen tenderer dog til at være mere restriktiv i de nordiske lande.

I det følgende sammenlignes udbudsstyringen i Norge, Sverige og Danmark med Holland.

\section{Case study: Udbudsstyring af videregående uddannelser i Norge, Sverige, Danmark og Holland}

Sammenlignet med øvrige europæiske lande ses en vis variation i styring af udbuddet af uddannelsespladser på de videregående uddannelser, herunder hvorvidt dimensionering anvendes som styringsredskab til udbudsregulering og sikring af en regional uddannelsesdækning.

I Norge har universiteter og videnskabelige højskoler som udgangspunkt ret til at udbyde nye videregående uddannelser uden dimensionering, mens højskoler, der er godkendte udbydere af videregående uddannelser, kan udbyde nye uddannelser til og med bachelorniveau med nogenlunde frit optag. Øvrige højskoler kan kun udbyde uddannelser efter forudgående uddannelsesakkreditering. Hvis en institution ønsker at få udvidet sin udbudsret, kan institutionen blive godkendt hertil efter en positiv institutionsakkreditering. Styring af uddannelsernes geografiske placering og den regionale spredning af uddannelsesudbuddene reguleres således ikke direkte gennem dimensionering. 
I Sverige er modellen for akkreditering af de videregående uddannelser løbende blevet revideret gennem de seneste 10 år. I perioden 2001-2007 blev alle videregående uddannelsesinstitutioner og deres uddannelsesudbud på alle niveauer evalueret. Konsekvensen af en negativ evaluering kunne være, at institutionen mistede eksaminationsretten for den pågældende uddannelse. I samme periode blev der gennemført uddannelsesakkreditering af nye erhvervsrettede uddannelser. Fra 2007 er der også blevet foretaget uddannelsesakkreditering af nye ph.d.-programmer, som er oprettet af andre institutioner end universiteterne. Tilsvarende Norge er den svenske styring af uddannelsernes geografiske placering og den regionale spredning af uddannelsesudbuddene ikke direkte omfattet af akkrediteringssystemet.

Omvendt anvendes i Holland en model, hvor akkreditering af nye videregående uddannelser eksplicit kombineres med en faglig-politisk-økonomisk overvågning og styring af væksten i nye uddannelser. Dette indebærer, at institutionerne kun kan søge om akkreditering af nye uddannelser med ministerens tilladelse. Tilsvarende skal ministeren give tilsagn til væsentlige ændringer inden for de eksisterende uddannelser, herunder særligt institutionernes ønsker om at oprette udbudssteder uden for den kommune/region, hvor institutionen er hjemhørende.

Den hollandske minister baserer sine afgørelser på indstillinger fra en dertil nedsat kommission, der sammensættes for en 4-årig periode af personer med et bredt kendskab til de videregående uddannelser. Den nuværende ordning, hvor den faglige kommission vurderer hensigtsmæssigheden af nye uddannelser forud for akkrediteringen, blev indført i 2009. Tidligere kunne institutionerne frit søge om akkreditering, og ministerens indflydelse var begrænset til muligheden for at standse en ny uddannelse efter gennemført akkreditering.

Ministeren baserede sig før 2009 på en samfundsøkonomisk vurdering, som blev gennemført i ministeriet. Ordningen gav imidlertid anledning til store udsving, hvor antallet af nye uddannelser i nogle ministerperioder var voldsomt stigende. Med den nye ordning søgte man fra 2009 i højere grad at tydeliggøre det samlede uddannelsesbillede og skabe en kollektiv indsigt, der kunne understøtte sektorens bevidsthed om relevansen af nye uddannelser og udbud samt relevansen af dimensionering af eksisterende uddannelser.

Det danske billede er præget af akkrediteringens stigende betydning. Et uafhængigt akkrediteringsråd med et sekretariat har fra 2008 stået for indstillinger til Videnskabs - nu Uddannelsesministeriet. I Danmark gennemførte man et meget strikt adgangsreguleringssystem fra slutningen af 1970'erne. Senere blev det blødt op, og man fik i stedet et system med frit optag, dog stadig med regulering for lægestudiet, særligt populære humanistiske fag mv.

Reguleringen er nu overladt til de enkelte universiteter og deres fakulteter. Men Ministeriet kan stadig give henstillinger til de enkelte universiteter og lave aftaler med dem. For KVU og MVU er billedet mere centralistisk. 


\subsection{Unges opfattelse af de enkelte fagområder}

De unges opfattelse af forskellige uddannelsesområder er både interessant i sig selv og af betydning for den fremtidige fagfordeling.

Det er generelt meget forskelligt, hvilke fag der tiltaler henholdsvis unge drenge og unge piger. I de nordiske lande - som i andre OECD-lande er det de tekniske uddannelser, der tiltaler de unge drenge mest, mens de blødere uddannelser tiltaler de unge piger mest. Dog er der en tendens til, at det naturvidenskabelige felt generelt har fået fat i pigerne, og der er flere piger, der forventer, at de vil beskæftige sig med naturvidenskab.

Nedenstående tabel viser, hvor mange 15-årige, der forventer en karriere inden for naturvidenskab generelt og mere specifikt inden for teknik og IT-videnskab. I Norden ligger kun Norge og Island over OECDgennemsnittet på ca. 33 pct. af alle 15-årige studerende. Særligt Island ligger meget højt. Finland ligger lavest af de nordiske lande med ca. 23 pct.

For teknisk- og IT-videnskab er billedet anderledes for fordelingen mellem piger og drenge, der forventer en karriere. I OECD er der over fire gange så mange drenge som piger, der forventer en karriere inden for teknik- og IT-videnskab. Dette mønster går igen for de nordiske lande. Især i Finland er forskellen mellem piger og drenges forventninger stor. Her er der fem gange så mange drenge som piger, der forventer en karriere inden for teknisk- og IT-videnskab.

Ser man på alle 15-årige studerende, er det kun Norge med en større andel end OECD, der forventer en karriere inden for teknisk- og ITvidenskab. Finland og Danmark er de to nordiske lande, der ligger længst fra OECD-gennemsnittet.

Tabel 3.6: 15-åriges forventninger til en karriere inden for naturvidenskab

\begin{tabular}{lcccccc}
\hline & $\begin{array}{c}\text { Andel 15-årige, der forventer en karriere } \\
\text { inden for naturvidenskab }\end{array}$ & $\begin{array}{c}\text { Andel 15-årige, der forventer en karriere } \\
\text { inden for Teknisk- og IT-videnskab }\end{array}$ \\
& $\begin{array}{c}\text { Alle 15 årige } \\
\text { studerende }\end{array}$ & Drenge & Piger & $\begin{array}{c}\text { Alle 15 årige } \\
\text { studerende }\end{array}$ & Drenge & Piger \\
& 28,4 & 24,3 & 32,6 & 8,2 & 13,0 & 3,3 \\
Danmark & 23,2 & 21,3 & 24,8 & 6,0 & 10,5 & 2,1 \\
Finland & 39,8 & 36,8 & 42,5 & 10,6 & 14,1 & 7,5 \\
Island & 34,4 & 30,4 & 38,3 & 13,4 & 19,4 & 7,4 \\
Norge & 26,9 & 25,4 & 28,5 & 9,8 & 15,3 & 4,4 \\
Sverige & 33,2 & 33,1 & 33,2 & 11,3 & 18,2 & 4,6 \\
OECD & & & & & & \\
\hline
\end{tabular}

Kilde: Education at a Glance 2012, tabel A4.2. I Teknisk- og IT-videnskab er der inkluderet arkitekter.

Grunden til, at en mindre andel piger end drenge forventer en karriere inden for teknisk- og IT-videnskab er, at de ser sig selv i en blødere karriere. Dette er vist i nedenstående tabel, der viser en oversigt over hvor stor en andel 15-årige drenge og piger, der forventer en karriere inden for sundhedsvæsnet ekskl. sygeplejersker og jordemødre.

Tabellen viser først og fremmest, at alle nordiske lande undtagen Island har en mindre andel af 15-årige, der forventer en karriere inden for sund- 
hed end OECD generelt. I Island er der næsten 15 pct. af de 15 årige, der forventer en karriere inden for sundhed. Der er her en diskrepans mellem de 15-åriges forventninger og den fordeling, man faktisk ser pt., jf. tidligere afsnit. Da det sundhedsfaglige område er mere reguleret end andre områder, vil præferencerne hos de helt unge ikke nødvendig vis slå igennem

Forskellen mellem drenges og pigers forventninger er generelt stor $\mathrm{i}$ OECD. Således er der næsten dobbelt så mange 15 årige piger som drenge, der vil vælge denne karrierevej. For Sverige, Norge, Finland og Danmark er forskellen dog større.

Tabel 3.7: 15-åriges forventninger til en karriere inden for sundhed og service.

Andel 15-årige, der forventer en karriere inden sundhed og service

Alle 15 årige studerende

Drenge Piger

\begin{tabular}{lrrr}
\hline Danmark & 10,5 & 5,4 & 15,8 \\
Finland & 9,1 & 4,6 & 12,8 \\
Island & 14,6 & 10,0 & 18,8 \\
Norge & 10,1 & 4,7 & 15,5 \\
Sverige & 8,2 & 4,3 & 12,1 \\
OECD & 11,5 & 7,1 & 15,7
\end{tabular}

Kilde: Education at a Glance 2012, tabel A4.3. sundhed er ekskl. sygeplejersker og jordemødre. 


\section{Frafald og studietider}

Der findes mange forskellige måder at måle en fuldførelsesprocent på. Forløbsmetoder, tværsnitsmetoder etc. I OECD-statistikken bruges en kombination af en forløbsmetode (True cohort) og tværsnit (cross section).

For at tage højde for disse forskelle og for at kontrollere resultaterne har Epinion gennemført en beregning efter den meget simple årgangsforskydningsmetode. Der er en forbløffende god overensstemmelse mellem resultaterne. Danmark har den højeste fuldførelsesprocent med ca. 80 pct., fulgt af Finland og Island med ca. 70 pct., Norge med ca. 60 pct. og Sverige med ca. 50 pct. Når Sverige ligger særligt lavt, skyldes det det modulopbyggede system, hvor frafaldsregistreringen kan være mere sikker end fuldførelsen på den samlede uddannelse.

Tabel 4.1: Fuldførelsesprocenter for ISCED 5A. "True cohort"-metode. 2008

\begin{tabular}{lr}
\hline & Samlet \\
\hline Danmark & $82^{*}$ \\
Norge & 63 \\
Sverige & $49^{* *}$ \\
Finland & 72 \\
Island & 72 \\
Norden-gennemsnit & 64 \\
OECD-gennemsnit & 70 \\
EU-19-gennemsnit & 70 \\
\hline
\end{tabular}

Kilde: Education at a Glance 2010.

* Dansk metode: Cross-section.

** Svenske tal inkluderer studerende på enkeltkurser, som ikke nødvendigvis behøver at deltage i alle kurser for at opnå deres grad.

Tabel 4.2: Fuldførelsesprocenter baseret på årgangsforskydningsmetoden for bachelorer (3 år)

\begin{tabular}{lccc}
\hline & Mænd & Kvinder & Total \\
\hline Danmark & 75 & 86 & 81 \\
Finland & 46 & 67 & 58 \\
Sverige & 40 & 57 & 50 \\
Island & 59 & 83 & 73 \\
Norge & 63 & 72 & 68 \\
Nordisk gennemsnit & 56 & 73 & 66 \\
\hline
\end{tabular}

Kilde: Beregnet ud fra Eurostat 2009.

Der er kun gennemført årgangsforskydning med en studietid på 3 år svarende til en bacheloruddannelse. Resultaterne på med en forskydning i forhold til kandidatniveau giver mange metodiske problemer med denne simple metode. I Sverige opereres med det interessante begreb: Præstationsgrad. Performanceindikatoren er antal performance point sammenlignet med full-time æquivalenter. Generelt for højere uddan- 
nelse i Sverige faldt den fra 84 til 79 pct. fra 2004/5 til 2009/10. Generelt ligger graduation rate på mellem 33 og 90 pct.

Medicin i Sverige ligger højest med 90 pct., men også på andre sundhedsvidenskabelige studier som Sygeplejersker og jordemødre ligger vældig højt. Lavest ligger i Sverige engineering og architecture med mellem 33 og 48 pct. Mange her havde en anden grad (10 pct.) Det kan forklare noget i relation til den relativt lave fuldførelse. Der er en bemærkelsesværdig forskel på mænd og kvinder. Kvinderne ligger i gennemsnit på alle uddannelsesprogrammer med en pct., der er 5-10 pct. højere end mændenes.

Et dansk case fra den såkaldte uddannelsesprofilmodel viser, at der er en del frafald fra det videregående uddannelsessystem, men ikke så stort som fra det erhvervsfaglige niveau.

\section{Figur 4.1: Uddannelsesprofil - et dansk case fra 2010}

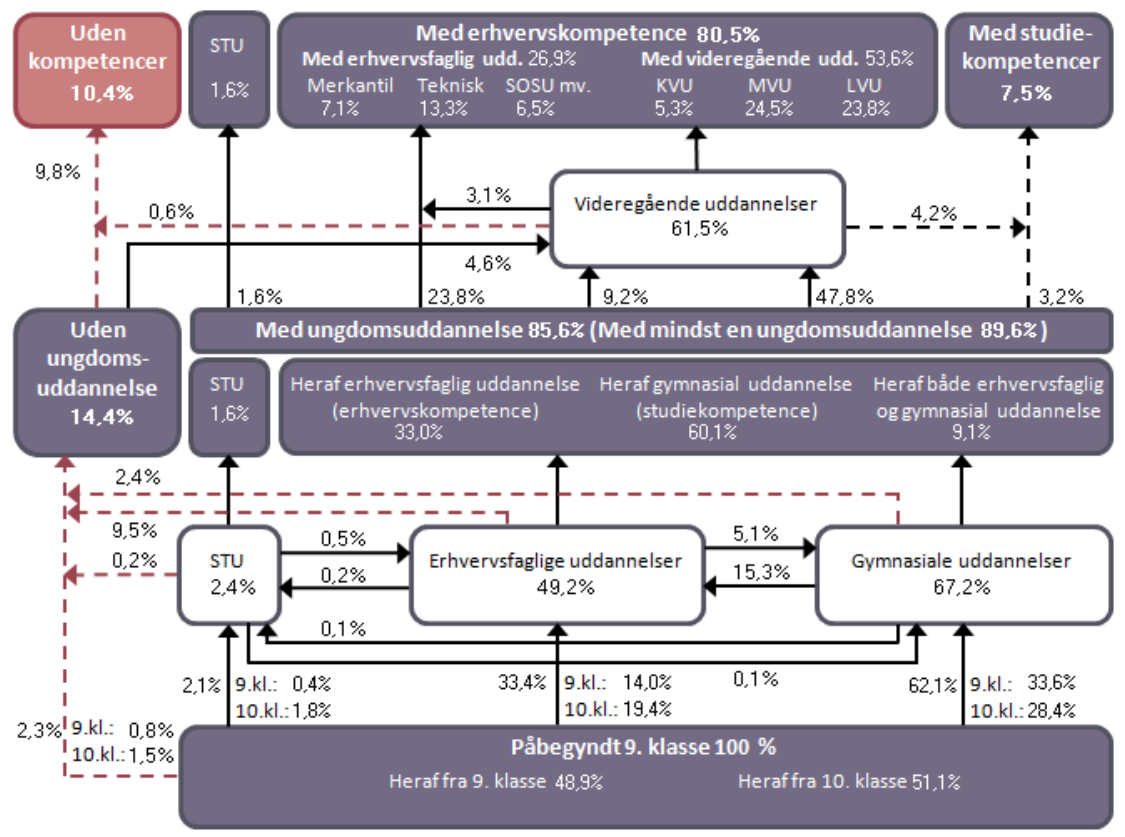

Den store joker i frafaldsanalyser i alle de nordiske lande er, hvor stor en andel af de afbrudte, som er studieskiftere (Trendeduc for det danske Uddannelsesministerium 2007). Den generelle tommelfingerregel er, at op til 80 pct. af de afbrudte reelt er studieskiftere. Enten skifter de fra et videregående uddannelsesområde til et andet, eller de skifter til lavere uddannelsesniveau, f.eks. det erhvervsfaglige niveau.

Det bør være en vigtig bestræbelse for fremtidig uddannelsesstatistik/analyse i Norden, at der skelnes mellem studieskiftere og "totalafbrud." Studieskiftsfænomenet er ikke af ny dato. Allerede i middelalderens nordiske lande skiftede afbrudte fra teologistudiet ofte til at blive 
"degne". Degn var ganske vist ikke en formel uddannelse, men dog et job, der krævede intern oplæring i kirkens system.

Der er rigtig mange studieskiftere fra lange, teoretisk prægede akademiske uddannelser til mere praktiske uddannelse som lærer/sygeplejerske/pædagog og også studieskiftere mellem de enkelte uddannelsesområder. Som det svenske eksempel viser, er der også stor forskel på afbrud på ordinær uddannelse og mere kursistprægede forløb.

Her bør fremtidig nordisk statistik skelne mere klart, selvom den faglige udvikling nærmest peger i den modsatte retning, idet der kommer mere og mere efteruddannelse.

Uddannelsestiden er en særlig vanskelig variabel. Svenske og danske undersøgelser peger på hyppige tilfælde af tilbagevenden både efter fuldførelse og efter afbrud. Dette komplicerer opgørelsen af samlet studietid.

En svensk undersøgelse (Høgskoleverket 2012: Studenternes studiemønster og totale studietider) viser, at af alle nybegyndere på videregående uddannelsesinstitutioner i perioden 1978/79-1997/98 er over 40 pct. vendt tilbage efter en afsluttet studieperiode. Blandt kvinderne er det over halvdelen og for mændene 1/3. Der er også mange en-termin studerende som har været registreret på fritstående kurser og er betydeligt ældre end de øvrige. Eksamensfrekvensen var 83 pct. for kvinder og 66 pct. for mænd. 



\section{Nordisk og international mobilitet}

Et forhold af væsentlig betydning er den mobilitet, der finder sted i forbindelse med uddannelse, idet denne er betydelig. Der findes forskellige studier af studentermobilitet og -udveksling, som bl.a. viser, at blandt nordiske studerende, der tager en fuld uddannelse i udlandet, tager majoriteten uddannelses i et andet nordisk land jf. nedenstående figur 5.1.1

De enkelte nordiske lande laver opgørelser over antallet af studerende fra Norden, der rejser til andre nordiske lande for at studere en hel uddannelse. Opgørelserne tager udgangspunkt i indberetninger fra uddannelsesinstitutionerne og viser, hvor mange som er indskrevet på en hel uddannelse.

Figur 5.1: Nordiske full degree studerende i udlandet fordelt på oprindelsesland

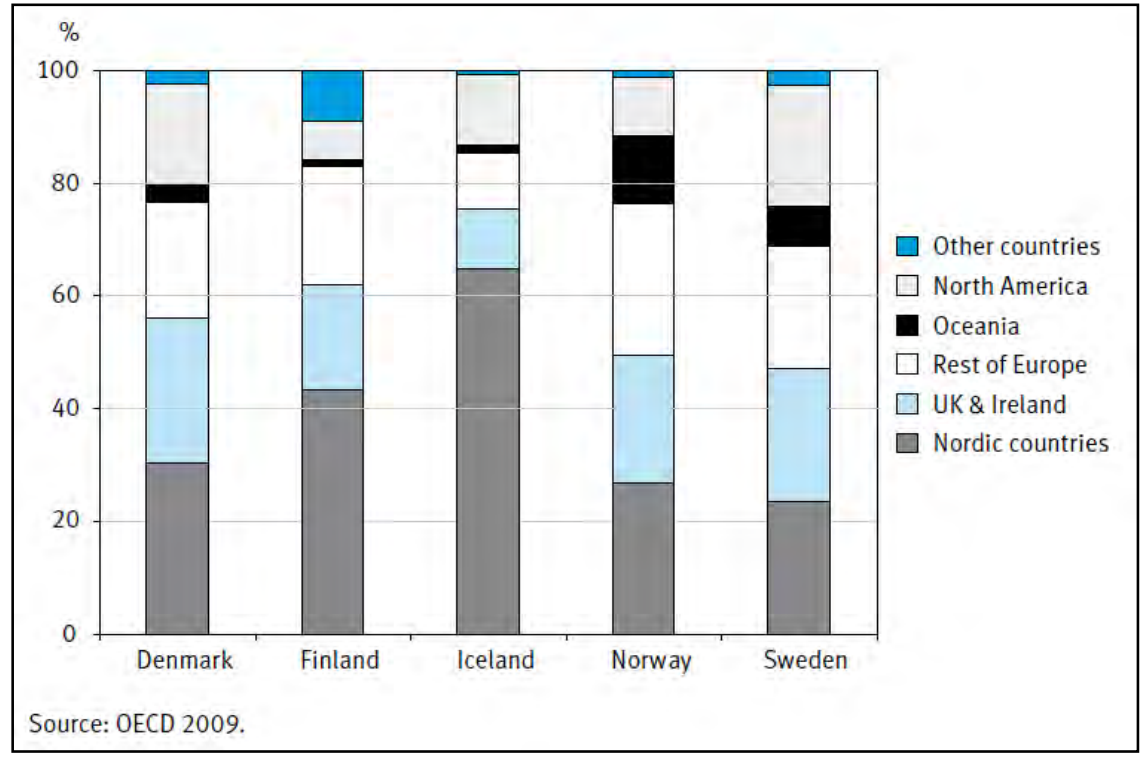

1 Miia Saarikallio-Torp \& Jannecke Wiers-Jenssen (eds.) (2010) Nordic students abroad. Student mobility patterns, student support systems and labour market outcomes. KELA, Research Department. Finland. Figur 1.4 p. 28. 
Billedet ser dog anderledes ud for studerende, der kun tager en del af sin uddannelse (typisk et semester) i udlandet, idet disse studerende i overvejende grad drager til anglosaksiske lande.

I det følgende vil mobiliteten i Norden blive beskrevet. Tabel 5.1 viser hvor stor en andel af alle de studerende på videregående uddannelser, der udgøres af hhv. internationale og udenlandske studerende. Særligt interessant er de internationale studerende dvs., de, der flytter til et land med det formål at studere der.

Tabel 5.1: Andele af internationale og udenlandske studerende på de videregående uddannelser (2009)

\begin{tabular}{lrr}
\hline & $\begin{array}{r}\text { Internationale } \\
\text { studerende }\end{array}$ & $\begin{array}{r}\text { Udenlandske } \\
\text { studerende }\end{array}$ \\
\hline Danmark & 5,4 & 9,6 \\
Finland & 3,7 & 4,2 \\
Island & 4,6 & 5,5 \\
Norge & 2,3 & 8,0 \\
Sverige & 6,4 & 9,4 \\
Nordisk gennemsnit & 4,5 & 7,3 \\
OECD & 6,4 & 8,7 \\
EU-21 & 5,4 & 7,7 \\
\hline
\end{tabular}

Kilde: Education at a Glance 2011 s. 333.

Note 1: Man klassificeres som international studerende, hvis man er flyttet fra sit fødeland med det formål at studere i et andet land. Man klassificeres som udenlandsk studerende, hvis man ikke er statsborger i det land, hvor man studerer.

Note 2: De danske data for internationale studerende fra Education at a Glance er en smule underestimeret. Tallet burde således ligge på mellem 7pct.-8pct.

Hvis man ser på et gennemsnit for de nordiske lande må man konstatere, at Norden halter en smule bagefter, når det gælder om at tiltrække internationale studerende med en andel på 4,5 ift. OECD og EU-21 der ligger på hhv. 6,4 og 5,4 pct. Internt i Norden er der ret markante forskelle. Sverige ligger højt med 6,4 pct. efterfulgt af Danmark med 5,4 pct. Norge og Finland ligger ret lavt med hhv. 2,3 og 3,7 pct. Island placerer sig i midten med en andel på 4,6 pct. internationale studerende.

I tabel 5.2 kan man se, hvilke typer og uddannelsesniveauer de internationale studerende besætter. For alle lande er det primært videregående type A programmer som optager internationale studerende. Danmark adskiller sig dog markant ved, at 19,7 pct. af de internationale studerende er optaget på videregående type B programmer. 
Tabel 5.2: Fordeling af internationale studerende på videregående uddannelser fordelt på niveau og type af tertiær uddannelse (2010)

\begin{tabular}{lrrr}
\hline & $\begin{array}{r}\text { Videregånde type B } \\
\text { programmer }\end{array}$ & $\begin{array}{r}\text { Videregående type A } \\
\text { programmer }\end{array}$ & Ph.d programmer \\
\hline Danmark & 19,4 & 71,6 & 9,0 \\
Finland & 0 & 86,8 & 13,2 \\
Island & 0,2 & 93,7 & 6,1 \\
Norge & 0,5 & 89,3 & 10,2 \\
Sverige & 0,2 & 84,5 & 15,3 \\
\hline
\end{tabular}

Kilde: Education at a Glance 2012, C4.1. Baseret på antal registreringer og ikke pr. hoved. Tallene summer til 100.

I Finland er det så godt som ingen der optages og i de andre nordiske lande er andelene meget små. I Finland og Sverige udgør de ph.d.studerende ret store andele af bestanden af internationale studerende. I Sverige er det hele 16,2 pct. og i Finland er det 13,5 pct.

Når man ser på de studerendes bevægelser, såkaldt inflow og outflow er der nogle ret markante forskelle landene imellem. Island ligger meget højt hvad angår outflow, hvor hele 19,5 pct. af de studerende på de videregående uddannelser studerer i udlandet. 46,5 pct. af de islandske studerende der rejser til udlandet søger til Danmark. ${ }^{2}$ Norge har det næststørste outflow med 5,3 pct. af de studerende. Resten af de nordiske lande ligger med andele mellem 2,5 og 3,2 pct., hvilket betyder at niveauet er det samme som EU-27, hvor det i gennemsnit er 2,7 pct. af de studerende, der søger til udlandet.

Figur 5.2: Outflow af studerende (ISCED 5-6) der studerer i et andet EU-27, EEA eller kandidatland. Som pct. af alle studerende

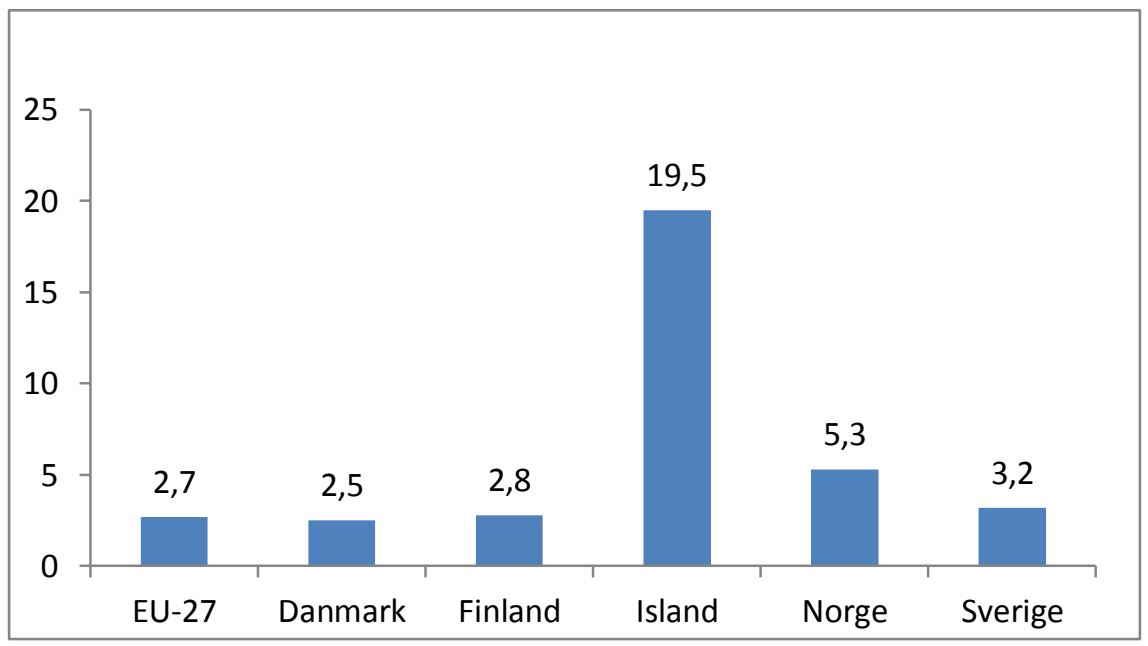

Kilde: Eurostat.

2 OECD: Education at a Glance 2011 s. 336. 
Når man ser på inflow er Danmark med 6,5 pct. det land, der tiltrækker flest studerende. Island formår også at tiltrække internationale studerende med en pct. på 4,1 Gennemsnittet for EU-27 ligger på 3,1 pct., hvilket er lidt højere end resten af de nordiske lande. Med blot 1,2 pct. er Finland ikke er land der tiltrækker mange internationale studerende.

Figur 5.3: Inflow af studerende (ISCED 5-6) fra EU-27, EEA eller kandidatland. Som pct. af alle studerende i landet

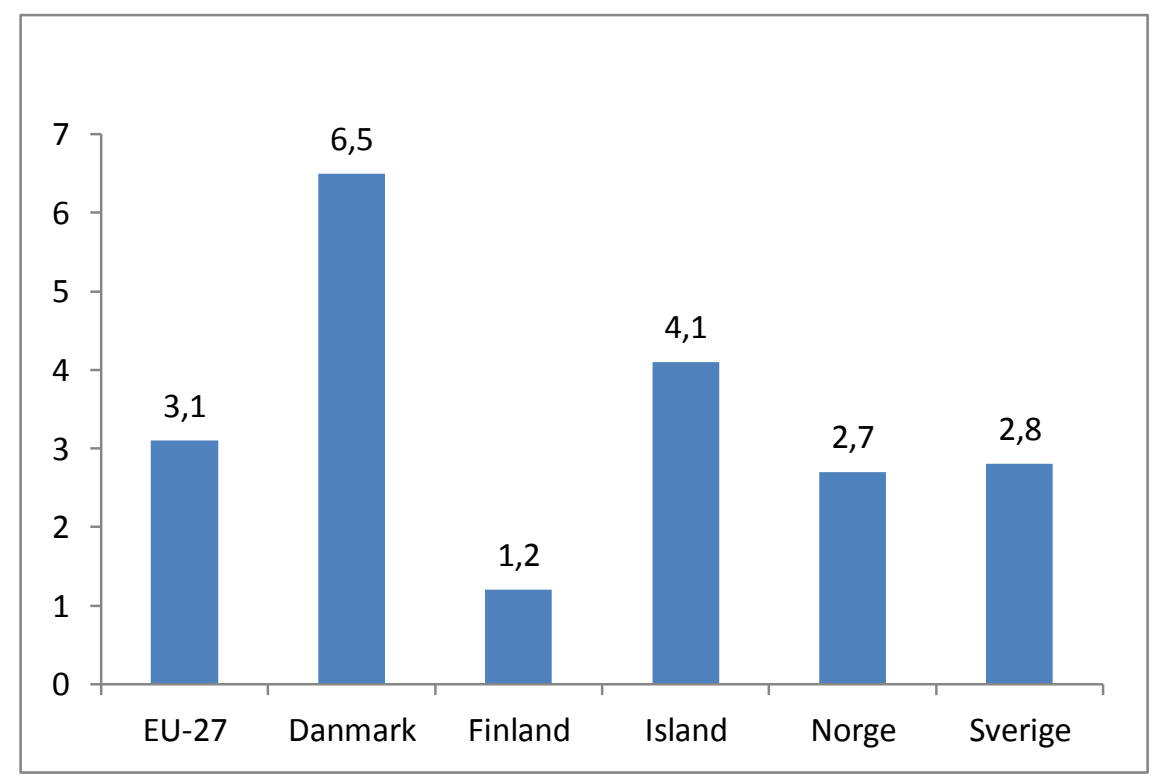

Kilde Eurostat.

Figur 5.4 Netto inflow af studerende (ISCED 5-6) fra EU-27, EEA eller kandidatland. Som pct. af alle studerende i landet

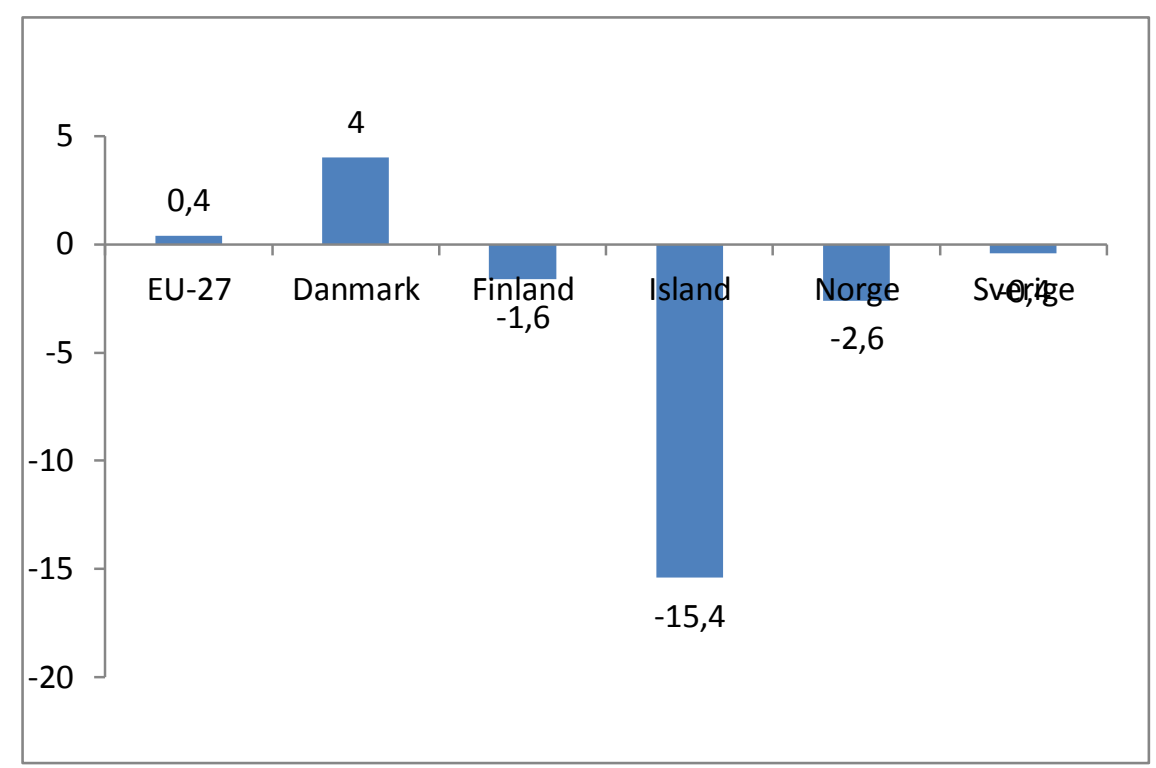


De studerendes mobilitet er belyst i hhv. tabel 5.3 og 5.4. Samlet set er der gennem de sidste blevet en mere klar tendens til at de studerende tager på studieophold i udlandet. I EU-27 og i Norden har der været en tilsvarende udvikling.

Tabel 5.3: Outflow af studerende (ISCED 5-6) der studerer $i$ andre EU-27, EEA eller kandidatland over tid - som pct. af alle studerende

\begin{tabular}{lrrrrrrrrrr}
\hline & $\mathbf{2 0 0 0}$ & $\mathbf{2 0 0 1}$ & $\mathbf{2 0 0 2}$ & $\mathbf{2 0 0 3}$ & $\mathbf{2 0 0 4}$ & $\mathbf{2 0 0 5}$ & $\mathbf{2 0 0 6}$ & $\mathbf{2 0 0 7}$ & $\mathbf{2 0 0 8}$ & $\mathbf{2 0 0 9}$ \\
\hline EU-27 & 2,1 & 2,1 & 2,1 & 2,2 & 2,2 & 2,3 & 2,6 & 2,7 & 2,8 & 2,7 \\
Danmark & 2,7 & 2,6 & 2,6 & 2,7 & 2,5 & 2,3 & 2,6 & 2,5 & 2,4 & 2,5 \\
Finland & 3,2 & 3,0 & 3,0 & 3,0 & 2,9 & 2,7 & 3,0 & 2,9 & 2,7 & 2,8 \\
Island & 16,9 & 16,3 & 15,3 & 15,7 & 15,5 & 17,0 & 17,4 & 17,8 & 18,2 & 19,5 \\
Norge & 4,7 & 4,9 & 4,6 & 4,5 & 4,7 & 4,8 & 4,9 & 5,0 & 5,1 & 5,3 \\
Sverige & 2,7 & 2,7 & 2,4 & 2,3 & 2,2 & 2,3 & 2,7 & 3,0 & 3,0 & 3,2 \\
\hline
\end{tabular}

Kilde: Eurostat.

Tabel 5.4: Inflow af studerende (ISCED 5-6) fra EU-27, EEA og kandidatlande - som pct. af alle studerende $I$ et land

\begin{tabular}{lrrrrrrrrrr} 
& $\mathbf{2 0 0 0}$ & $\mathbf{2 0 0 1}$ & $\mathbf{2 0 0 2}$ & $\mathbf{2 0 0 3}$ & $\mathbf{2 0 0 4}$ & $\mathbf{2 0 0 5}$ & $\mathbf{2 0 0 6}$ & $\mathbf{2 0 0 7}$ & $\mathbf{2 0 0 8}$ & $\mathbf{2 0 0 9}$ \\
\hline EU-27 & 2,4 & 2,4 & 2,4 & 2,5 & 2,5 & 2,6 & 2,9 & 3,0 & 2,9 & 3,1 \\
Danmark & 2,6 & 2,8 & 3,0 & 3,5 & 3,5 & 3,9 & 4,5 & 4,9 & 5,3 & 6,5 \\
Finland & 0,8 & 0,9 & 0,9 & 1,0 & 1,0 & 1,0 & 1,1 & 1,2 & 1,2 & 1,2 \\
Island & 3,2 & 3,2 & 3,1 & 3,3 & 2,2 & 2,2 & 3,3 & 3,7 & 3,6 & 4,1 \\
Norge & 2,0 & 2,2 & 2,2 & 2,2 & 2,4 & 2,5 & 2,6 & 2,7 & 2,7 & 2,7 \\
Sverige & 4,2 & 4,3 & 4,3 & 4,3 & 4,5 & 4,6 & 4,8 & 5,0 & 2,7 & 2,8 \\
\hline
\end{tabular}

Kilde: Eurostat.

\subsection{Push/pull-effekter}

Hvad er afgørende for, at studerende enten forlader eller rejser til Norden? Mobiliteten blandt de studerende er i høj grad bestemt af forskellige push/pull-faktorer:

- Push-effekter angår udbudssiden og er faktorer, der påvirker studerendes interesse og vil-lighed til at blive mobile.

- Pull-effekter angår efterspørgselssiden og er faktorer, der trækker de studerende i retning af (større) mobilitet.

Nedenstående tabel 5.5 anskueliggør disse effekter skematisk.

Tabel 5.5: Push/pull-effekter og barrierer i forhold til uddannelsesmobilitet

\begin{tabular}{|c|c|c|c|}
\hline & $\begin{array}{l}\text { Push } \\
\text { (udbud) }\end{array}$ & $\begin{array}{l}\text { Pull } \\
\text { (efterspørgsel) }\end{array}$ & Barrierer \\
\hline $\begin{array}{l}\varnothing \text { konomiske } \\
\text { faktorer }\end{array}$ & Udsigt til lav $\mid \varnothing n$ & $\begin{array}{l}\text { Uddannelsesst } \varnothing \text { tte } \\
\text { Karrieremuligheder }\end{array}$ & $\begin{array}{l}\text { Love og regler } \\
\text { Manglende oplysning } \\
\text { Sprog }\end{array}$ \\
\hline $\begin{array}{l}\text { Ikke- } \\
\varnothing \text { konomiske } \\
\text { faktorer }\end{array}$ & $\begin{array}{l}\text { Mistrivsel/diskrimination } \\
\text { Familiære forhold } \\
\text { Lav gennemførelsesprocent }\end{array}$ & $\begin{array}{l}\text { Uddannelseskvalitet/-udbud } \\
\text { Udlængsel/eventyrlyst } \\
\text { Landets omdømme }\end{array}$ & $\begin{array}{l}\text { Kultur } \\
\text { Bureaukrati } \\
\text { Kvoter }\end{array}$ \\
\hline
\end{tabular}


Spørgsmålet er herefter, hvad der findes af viden om, hvilke faktorer, der har betydning for uddannelsesmobilitet - samt hvor gennemsigtige disse er for aktørerne.

Det kan her nævnes, at der bl.a. er oparbejdet en systematisk viden i forbindelse med den store Eurostudent survey, som netop har kørt for 4. gang (www.eurostudent.eu). Danmark, Sverige, Norge og Finland deltager i Eurostudent, mens Island dog ikke gør - og Danmark er først kommet med fra den aktuelle 4. bølge.

I det følgende gengives udpluk af resultater fra Eurostudent, der bekræfter, at Norden er en attraktiv uddannelsesregion.

\section{Figur 5.6: Offentlig uddannelsesfinansiering og deltagerbetaling}

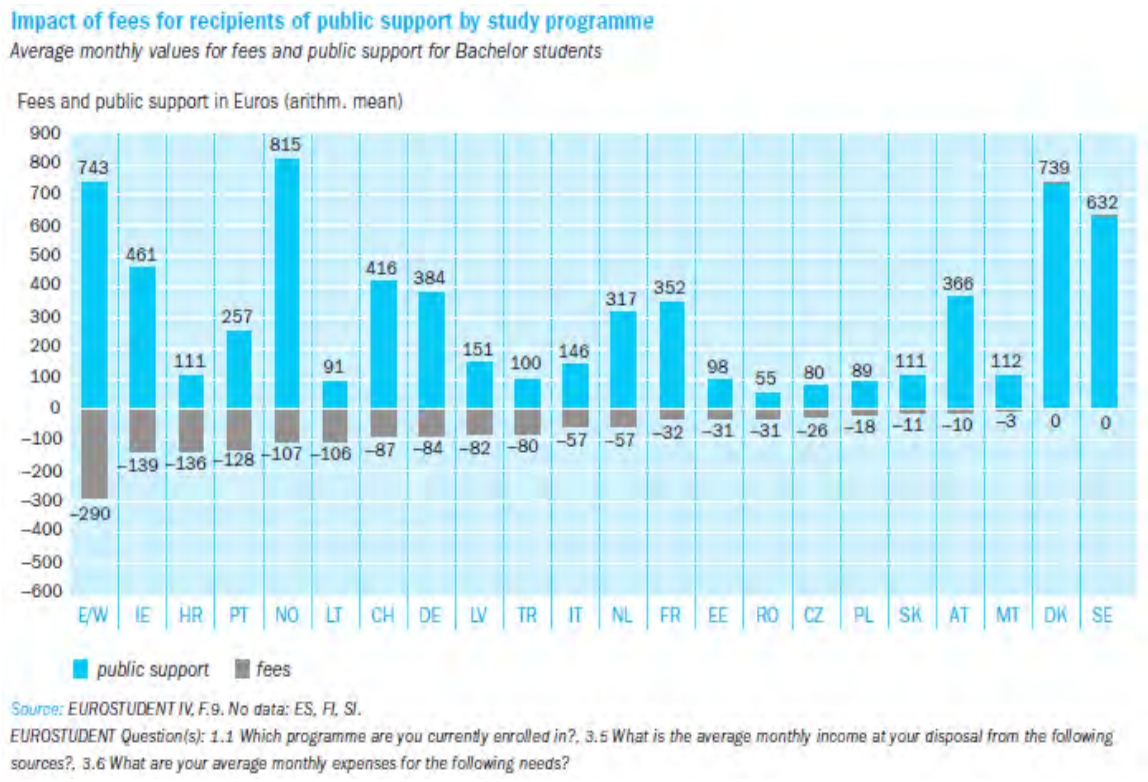

Af figur 5.6 ses det, at de nordiske lande er dem, hvor det offentlige bruger klart flest penge på uddannelse. 
Figur 5.7: Boligforhold

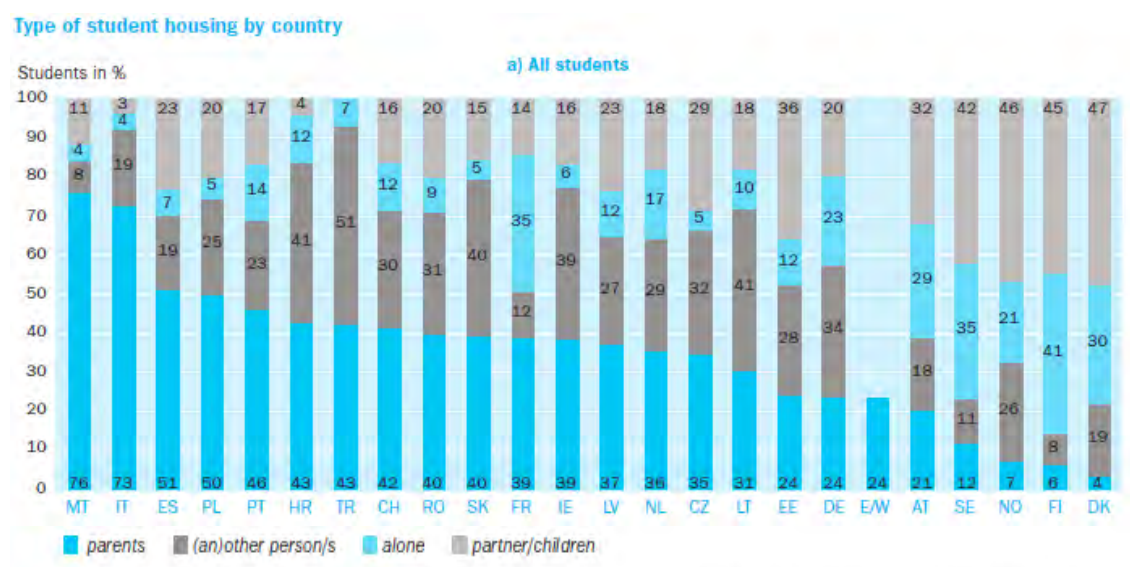

Source: EUROSTUDENT IV, D.1 \& D.2. No data: SL. No data for chart (a), (an)other person/s, alone: EN. No data for chart (a), partnerichilaren: ENW. TR. No data for chart (b), (an)other person/s, alane: EN. No data for chart (b). partner/chilaren: EN, TR.

EUROSTUDENT Question(s): 1.1 Which programme are you currenty enrolled in?. 3.1 Who do you live with during the study term/semester Monday unti) Friday)?

Af figur 5.7 fremgår det, nordiske studerende nyder større selvstændighed end i andre lande, idet det kun er de færreste, der bor hjemme hos forældrene, mens mange bor sammen med en partner.

\section{Figur 5.8: Udvekslingsstuderende}

Students who have made study-related experiences abroad by type of experience (multiple answers possible)

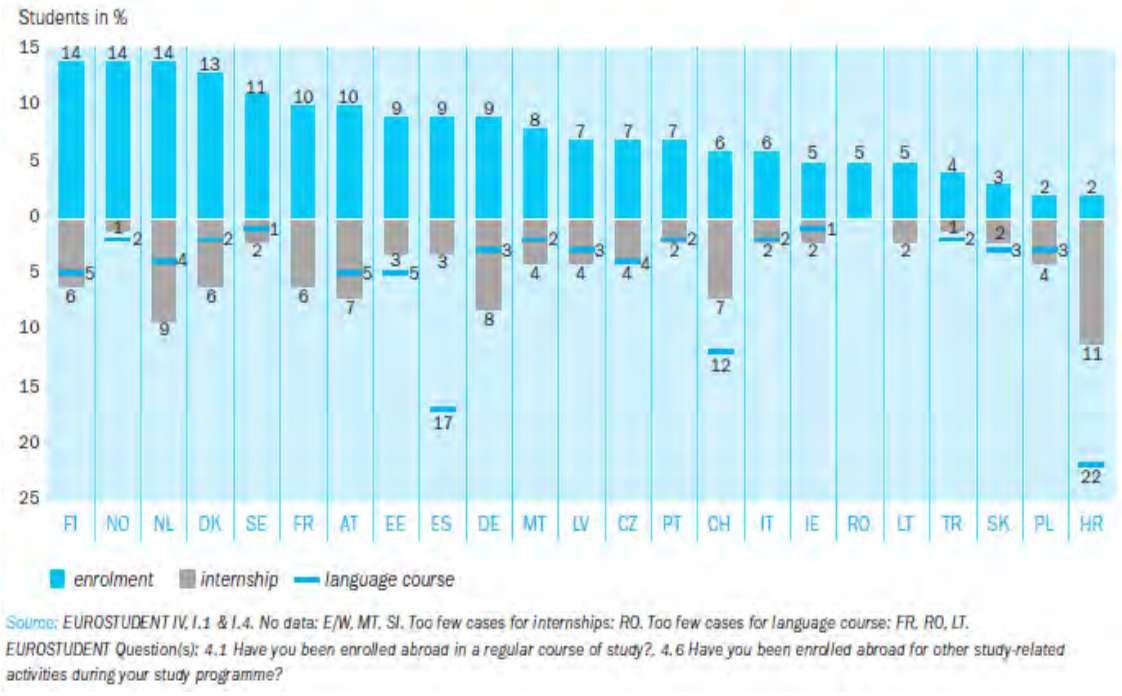

Af figur 5.8 ses det, at der blandt de nordiske studerende er mange, der har været på udenlandsophold, hvilket antageligvis giver dem et mere internationalt mind set, når de vender hjem. 


\section{Figur 5.9: Oplevelse af personlig udviklig}

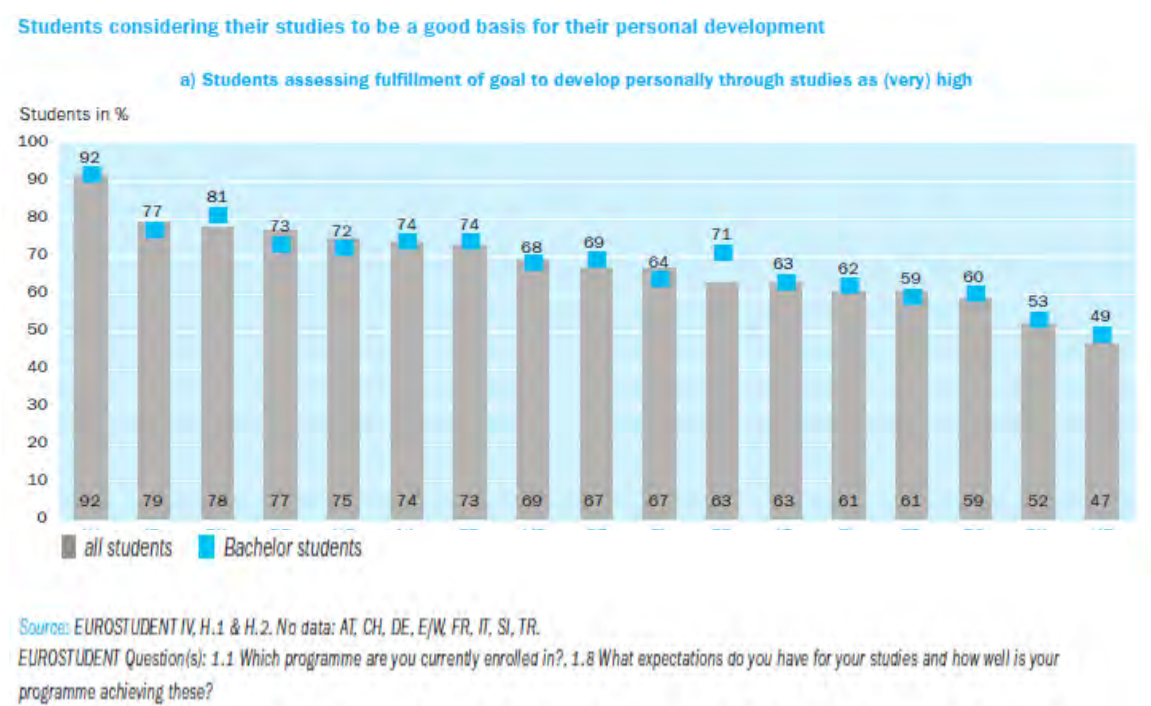

Af figur 5.9 fremgår det, at de nordiske studerende generelt ligger i den høje ende, når de skal vurdere, hvor vidt deres uddannelse danner god basis for deres personlige udvikling.

\section{Figur 5.10: Oplevelse af uddannelse som grundlag for at tage arbejde}

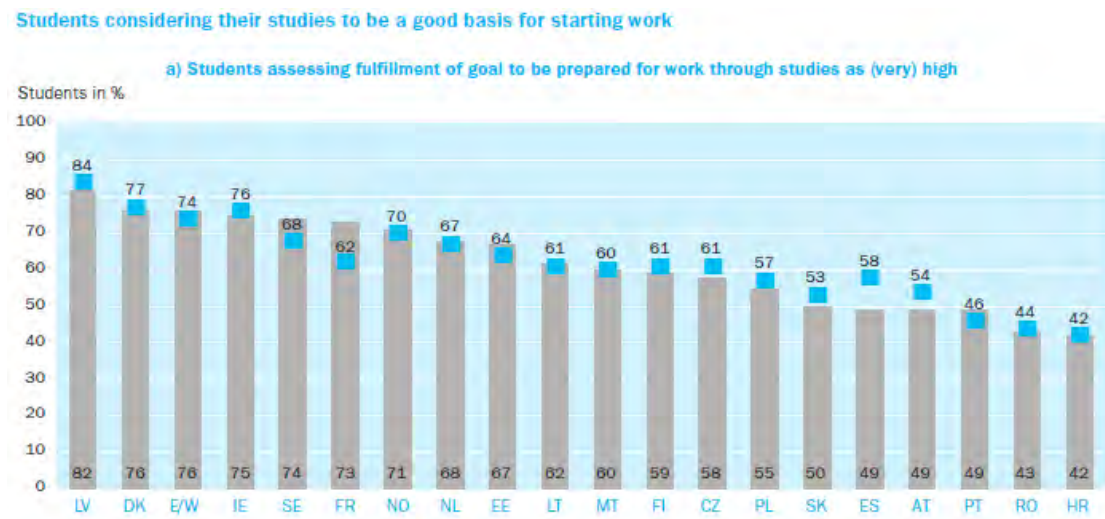

SQuics: EUROSSUDENTIV, H.1 1 H.2. No data: CH, DE, IT, SI, TR; No data for chart (b): EN, AT.

EUROSTLDENT Question(s): 1.1 Which programme are you currenty enralled in? 1.8 What expectations do you have far your studies and how well is your propramme achieving these?

Af figur 5.10 ses det, at de nordiske studerende også generelt vurderer, at deres uddannelse danner god basis for at tage arbejde efterfølgende. 


\section{Køn og social baggrund}

Europa-Kommissionen har som mål i deres "Europe 2020" strategiplan, at 40 pct. af de 30-34 årige skal have en uddannelse på tertiært niveau. Målet om at øge den videregående uddannelsesfrekvens gælder også i særlig grad for grupper, der har ressourcesvag socioøkonomisk baggrund, kommer fra udsatte geografiske lokationer, samt etniske mindretal. ${ }^{3}$

Dette kapitel vil i relation til disse målsætninger se nærmere på en række analyser af de studerendes profiler i de nordiske lande. Disse baggrundsanalyser vil blive præsenteret systematisk og komparativt, så der opnås et sammenligneligt overblik over de nordiske lande.

\subsection{Mænd og kvinder på de højere uddannelser}

I det følgende vil vi se på fordelingerne af køn på de videregående uddannelser.

Tabel 6.1 giver et indblik i, hvorledes de nordiske lande klarer sig ift. EU-kommissionens målsætning. I 2010 var andelen af 30-34 årige med en videregående uddannelse på 34 pct. for EU-27, hvilket betyder, at EU27 er 6 procentpoint fra målsætningen, om at 40 pct. af de 30-34 årige skal have en videregående uddannelse. Alle de nordiske lande lå i 2010 over dette niveau. Norden er samlet set markant foran resten af EU med et nordisk gennemsnit på 45 pct. Island trækker dog snittet lidt ned, hvor 41 pct. af de 30-34 årige har en videregående uddannelse.

\begin{tabular}{lccccc} 
Tabel 6.1: & $\mathbf{6}-\mathbf{3 4}$ årige med videregående (tertiær) uddannelse (pct.) Eurostat \\
\hline År & $\mathbf{2 0 0 1}$ & $\mathbf{2 0 0 5}$ & $\mathbf{2 0 0 7}$ & $\mathbf{2 0 0 9}$ & $\mathbf{2 0 1 0}$ \\
\hline EU-27 & 23 & 28 & 30 & 32 & 34 \\
EU-15 & 25 & 31 & 33 & 34 & 35 \\
Danmark & 33 & 43 & 43 & 48 & 47 \\
Finland & 42 & 44 & 47 & 46 & 46 \\
Island & 31 & 41 & 36 & 42 & 41 \\
Norge & 42 & 39 & 44 & 47 & 47 \\
Sverige & 27 & 38 & 41 & 44 & 46 \\
Nordisk gennemsnit & 35 & 40 & 40 & 43 & 43 \\
\hline
\end{tabular}

Generelt er der sket markante stigninger i uddannelsesniveauerne både i EU og i Norden. Særligt i Danmark og Sverige er andelen af 30-34 årige 
med videregående uddannelse steget, hvilket dog til dels - særligt i Danmarks tilfælde - kan tilskrives de øgede gennemførselstider (kilde), dvs. at de studerende simpelthen er hurtigere om at komme igennem uddannelsessystemet og at der er færre såkaldte "evighedsstuderende" der først bliver færdige i tredive årsalderen.

I Tabel 6.2 ses andelen af 25-34 årige med en videregående uddannelse. Denne tabel inkluderer de 25-29 årige, hvorfor den også giver et fingerpeg, om de seneste tendenser på de videregående uddannelser.

Tallene viser, at kvinder i højere grad opnår videregående uddannelse end mænd. Dette gør sig gældende både i EU og i Norden og at billedet har været således siden 2001 og i tiltagende grad.

Tabel 6.2: 25-34 årige med videregående (tertiær) uddannelse (pct.) Eurostat

\begin{tabular}{|c|c|c|c|c|c|c|c|c|c|c|c|c|c|c|c|}
\hline \multirow{2}{*}{$\begin{array}{l}\text { År } \\
\text { Land }\end{array}$} & \multicolumn{3}{|c|}{2001} & \multicolumn{3}{|c|}{2005} & \multicolumn{3}{|c|}{2007} & \multicolumn{3}{|c|}{2009} & \multicolumn{3}{|c|}{2010} \\
\hline & Total & $M$ & K & Total & $M$ & K & Total & $M$ & K & Total & $M$ & K & Total & M & K \\
\hline EU-27 & 24 & 22 & 25 & 28 & 25 & 31 & 30 & 26 & 34 & 32 & 28 & 36 & 33 & 29 & 38 \\
\hline EU-15 & 26 & 25 & 27 & 30 & 28 & 33 & 32 & 28 & 35 & 34 & 30 & 37 & 34 & 30 & 38 \\
\hline Danmark & 31 & 27 & 36 & 40 & 35 & 44 & 40 & 36 & 44 & 45 & 37 & 53 & 43 & 37 & 50 \\
\hline Finland & 38 & 30 & 46 & 38 & 28 & 47 & 39 & 31 & 48 & 39 & 30 & 49 & 39 & 31 & 48 \\
\hline Island & 27 & 25 & 30 & 36 & 30 & 42 & 33 & 29 & 37 & 36 & 30 & 42 & 36 & 29 & 44 \\
\hline Norge & 43 & 38 & 47 & 40 & 34 & 45 & 42 & 35 & 49 & 44 & 35 & 54 & 45 & 37 & 54 \\
\hline Sverige & 28 & 25 & 32 & 37 & 32 & 42 & 40 & 34 & 46 & 42 & 37 & 48 & 42 & 36 & 50 \\
\hline $\begin{array}{l}\text { Nordisk } \\
\text { gennemsnit }\end{array}$ & 33 & 29 & 38 & 38 & 32 & 44 & 39 & 33 & 45 & 41 & 34 & 49 & 41 & 34 & 49 \\
\hline
\end{tabular}

I takt med at andelen af de 25-34 årige med videregående uddannelse er steget er gabet mellem mænd og kvinder på de videregående uddannelser også steget. Fra 2001 til 2010 er andelen af 25-34 årige med en videregående uddannelse steget fra 24-33 pct. i EU-27, men gabet mellem mænd og kvinder er også steget fra 13 pct. til 30 pct. I Norden har der været en stigning fra 33-41 pct. i andel med videregående uddannelse. Samtidig er gabet mellem mænd og kvinder på de videregående uddannelser steget fra 32 til 45 pct. Særligt ses der store kønsgab i Finland og på Island, hvilket også er de to lande i Norden, hvor mændene halter mest bagefter uddannelsesmæssigt. Tallene indikerer at det særligt er kvinder, der formår at udnytte, når et land øger tilgangen til videregående uddannelser. 


\begin{tabular}{lcccccc}
\multicolumn{7}{l}{ Tabel 6.3: Kvinder ift. mænd på videregående uddannelser $\mathbf{2 5 - 3 4}$ årige (pct.), eurostat } \\
\hline År & $\mathbf{2 0 0 1}$ & $\mathbf{2 0 0 5}$ & $\mathbf{2 0 0 7}$ & $\mathbf{2 0 0 8}$ & $\mathbf{2 0 0 9}$ & $\mathbf{2 0 1 0}$ \\
\hline EU-27 & 13 & 22 & 27 & 28 & 29 & 30 \\
EU-15 & 10 & 19 & 24 & 25 & 24 & 26 \\
Danmark & 33 & 26 & 22 & 26 & 42 & 37 \\
Finland & 53 & 66 & 54 & 67 & 62 & 54 \\
Island & 22 & 43 & 29 & 40 & 39 & 54 \\
Norge & 23 & 34 & 42 & 48 & 51 & 45 \\
Sverige & 28 & 31 & 34 & 31 & 32 & 39 \\
Nordisk gennemsnit & 32 & 39 & 36 & 41 & 45 & 45
\end{tabular}

Tallene angiver kvindernes procentvise andel i forhold til mændenes andel på de videregående uddannelser. Positive tal afspejler et forspring til kvinderne.

\subsection{Kønsforskelle i uddannelsesvalg}

Inden vi fortsætter med analysen af EU-målsætningen vises med et dansk case hvor markante forskellene er. Forskellene i den kønsopdelte uddannelsesadfærd er kolossal i alle nordiske lande. Nedenstående danske case bekræfter det mere end nogen andre data. Pigerne står langt stærkere i det videregående uddannelsessystem, mens drengene står stærkt i det tekniske erhvervsfaglige system.

Figur 6.1. Uddannelsesprofil for drenge - et dansk case 2010

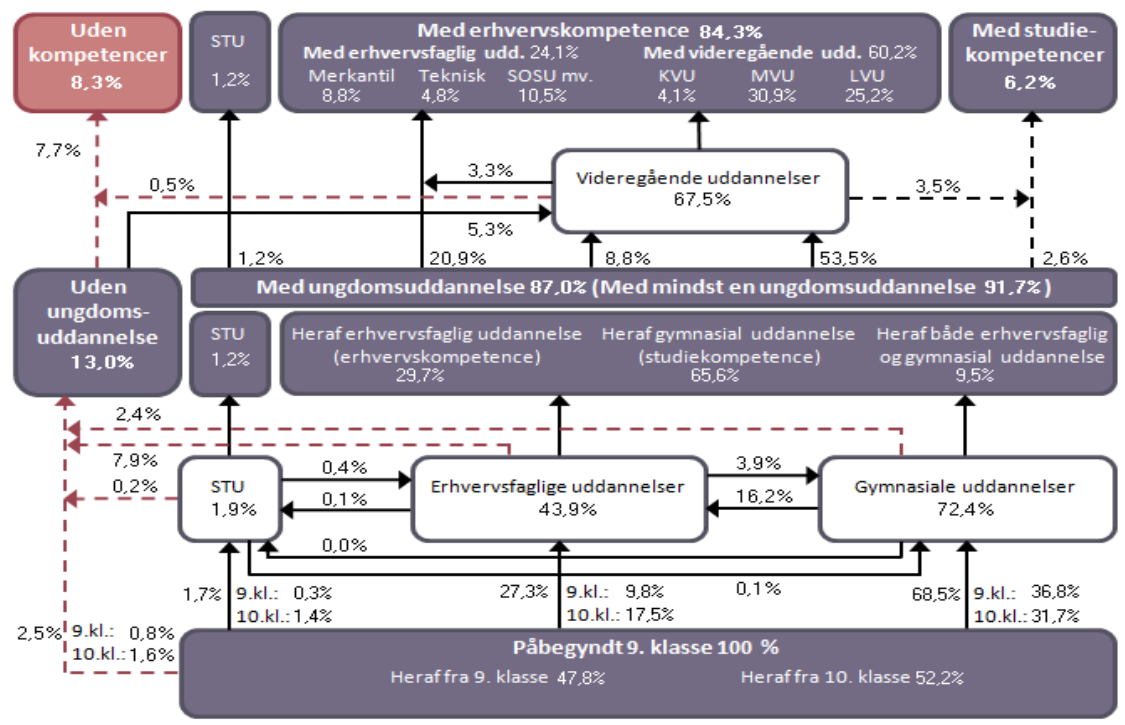


Figur 6.2: Uddannelsesprofil for piger - et dansk case 2010

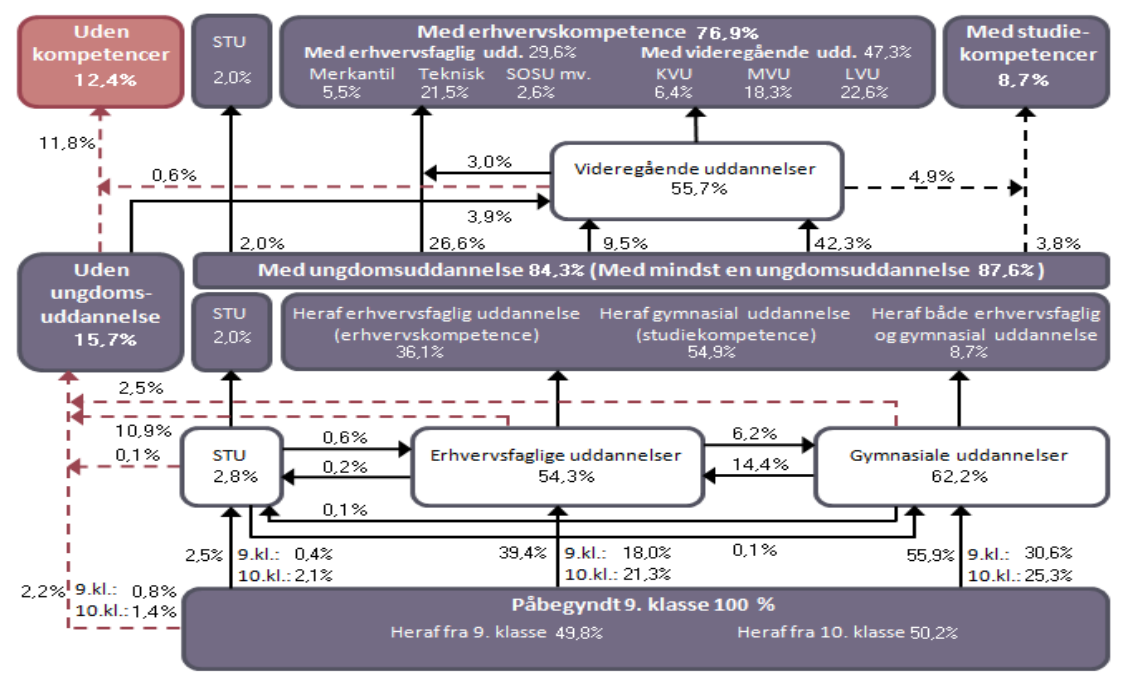




\section{Social uddannelsesmobilitet}

Den sociale rekruttering til universitets- og forskeruddannelserne har over tid og på tværs af lande altid været præget af skævhed. Det vil sige, at et barn af akademikerforældre har langt større chance for at opnå en lang videregående uddannelse end et barn af forældre som er ufaglærte. Det er både teoretisk og empirisk veldokumenteret, at social baggrund spiller en afgørende rolle for, hvem der får de høje uddannelser. For eksempel viser danske tal, at der er 10 gange så stor sandsynlighed for at opnå en ph.d.-grad, hvis ens far har en videregående uddannelse, som hvis han ingen uddannelse havde. ${ }^{4}$

\footnotetext{
"Social uddannelsesmobilitet kan defineres som den relative chance for at påbegynde og gennemføre en uddannelse, der er højere end den uddannelse, ens forældre har gennemført, når man sammenligner unge med forskellig social baggrund". 5
}

Et lands sociale uddannelsesmobilitet er lav, hvis afhængigheden af familiebaggrund er stor. Og den sociale uddannelsesmobilitet er høj, hvis afhængigheden er lille. Hvis social baggrund slet ikke har nogen betydning for sandsynligheden for at opnå en videregående uddannelse taler man om "Chancelighed i Uddannelse".

Der er god grund til at bekæmpe social arv i uddannelsessystemet. Politiske tiltag der tilsigter at højne social uddannelsesmobilitet har udover de individuelle gevinster - som sikring af, at folk kommer på deres rette hylde og udnyttelse af individernes kapacitet og evner - samtidig særdeles positive effekter for samfundsøkonomien. Dette er en konsekvens af, at en åben fluid social struktur har en større sandsynlighed for, at positioner, der kræver specielle færdigheder, faktisk besættes af individer med disse specielle færdigheder (high abilities). De samfund der har høj grad af fluiditet er dermed bedre til at tilpasse sig eksterne og interne forandringer. ${ }^{6}$ 
De baggrundsvariable, der gør sig gældende for mobilitetsprocesserne er forældreuddannelse, forældrenes beskæftigelse og geografiske forhold, dertil kommer en række individuelle forhold, som man kan forsøge at påvirke, når man laver tiltag mod social arv. F.eks. (nævn evt. eksempler fra anbefalinger til videnskabsministeren). Men også forhold i uddannelsessystemet, hvor reproduktionen af den sociale arv allerede starter i daginstitutionerne.

Tabel 7.1 giver et indblik i, hvorledes den sociale inklusion tager sig ud i de nordiske landes skolesystemer. Dette er relevant, fordi bruddet med den sociale arv ifølge SFI allerede starter i folkeskolen. Udtrykket inklusion bruges i bred forstand om skoler og skolesystemer, der støtter diversitet blandt elever. Høj grad af inklusion betyder samlet set bedre resultater samt mindre ulighed. ${ }^{7}$

Tabel 7.1: Indeks over social inklusion i folkeskolen

\begin{tabular}{lcr}
\hline & & \\
\hline & Vertikal inklusion $^{\mathbf{1}}$ & Horisontal inklusion $^{2}$ \\
\hline Denmark & 84,1 & 83,6 \\
Finland & 91,3 & 89,2 \\
Iceland & 85,9 & 82,8 \\
Norway & 89,7 & 91,2 \\
Sweden & 81,5 & 85,7 \\
Nordisk gennemsnit & 86,5 & 86,5 \\
OECD-gennemsnit & 61,4 & 74,8 \\
EU-15 & 57,3 & 71,6 \\
\hline
\end{tabular}

Kilde Education at a Glance s. 460.

Note 1: Vertikal inklusion: Indeks udregnet som $100^{*}$ (1-rho), hvor rho står for intraklasse korrelation af elevernes performance, som er variationen mellem skoler divideret med summen af variation i elevernes performance mellem skoler og variationen i elevernes performance indenfor skoler.

Note 2: Horisontal inklusion: Indeks udregnet som $100 *$ (1-rho), hvor rho står for intraklasse korrelationen af socioøkonomisk baggrund som er variationen i PISA indeks af social, økonomisk og kulturel status for studerende mellem skoler, divideret med summen af variation i elevernes socioøkonomiske baggrund mellem skoler og variationen i elevernes socioøkonomiske baggrund mellem indenfor skoler.

Vertikal inklusion er et indeks, der giver et indblik i i hvilken grad elever allokeres ud i skolesystemet på baggrund af deres evner, tidligere præstationer mv. Sådanne segregeringsmekanismer har tendens til at fordele dygtige og svage elever i forskellige skoler og forskellige klasser indenfor skoler. Hvis et land f.eks. tidligt i et skoleforløb indplacere ele-

7 OECD. Education at a Glance 2011: s. 455. 
verne på denne måde, er der tale om høj grad af vertikal separation og dermed er der i det pågældende land lav vertikal inklusion.

Alle de nordiske lande scorer højt på vertikal inklusion. Med et gennemsnit på 86,5 ligger Norden væsentlig højere end både OECD og EU-15 med gennemsnit på hhv. 61,4 og 57,3. Finland ligger meget højt på vertikal inklusion. Finland er desuden kendt for at have en god folkeskole med universitetsuddannede lærere ${ }^{8}$ og høj performance i PISA-undersøgelserne, hvor der er en meget lille andel af elever med dårlige læsekundskaber. ${ }^{9}$

Ikke blot i forhold til vertikal inklusion ligger de nordiske lande højt. Det gælder også horisontal inklusion. I et land, hvor der er lav grad af horisontal inklusion, er der tendens til, at elever med forskellig socioøkonomisk baggrund går i forskellige skoler. Høj horisontal inklusion betyder, at socioøkonomiske forskelle er udlignes mellem skoler.

Den horisontale inklusion ligger i Norden på 86,5, hvor OECD og EU15 ligger på hhv. 74,8 og 71,6. Norge ligger højest med en score på 91,2 efterfulgt af Finland, der ligger på 89,2. Danmark, Island og Sverige ligger lidt lavere på hhv. 83,6, 82,8 og 85,7.

Både i forhold til vertikal og horisontal inklusion ligger de nordiske landes folkeskoler særdeles højt i forhold til andre lande. Dette betyder, at der i Norden er gode forudsætninger for at bryde social arv videre op i uddannelsessystemerne.

\subsection{Chancelighed i uddannelse}

Tabel 7.2 giver et indblik i hvorledes forældres uddannelsesbaggrund påvirker chancerne for at få en videregående uddannelse (ISCED 5-6). Som tidligere beskrevet kan man definere chancelighed i uddannelse som den situation, hvor forældrenes uddannelse ingen indflydelse har på sandsynligheden for at få en videregående uddannelse.

Tallene er beregnet ud fra forældres uddannelsesbaggrund til folk med videregående uddannelse. Det antages, at absolut chancelighed for at opnå en videregående uddannelse udtrykkes ved, at der rekrutteres ligeligt fra alle niveauer af forældres uddannelser. Dvs. at forældres uddannelsesbaggrund på hhv. ISCED 0-2, 3-4 og 5-6 udgør lige store andele altså en tredjedel. Tallene i tabellen repræsenterer afvigelser fra chancelighed $(33,3)$.

Negative tal betyder, at forældres uddannelsesniveau har en negativ effekt på chancen for at opnå uddannelse på ISCED 5-6. Positive tal betyder, at der er forøgede chancer forbundet med forældres uddannel-

${ }^{8} \mathrm{http} / / /$ www.helsinki.fi/teachereducation/step/information/qualifications/index.html ${ }_{9}$ OECD. Education at a Glance 2011: s. 461. 
sesbaggrund og 0 angiver, at man med forældres uddannelsesbaggrund stilles med de samme chancer som gennemsnittet.

Betydningen af forældres uddannelsesbaggrund ses meget tydeligt i tabel 7.2. Hvis ens forældre er uddannede på ISCED 0-2 niveau stilles man chancemæssigt væsentligt ringere end andre. Ligeledes er der en markant chancemæssig fordel forbundet med at have forældre på ISCED niveau 5-6.

Tabel 7.2: Chancelighed i uddannelse (CLU) på ISCED 5-6 fordelt på forældrenes uddannelsesniveau 2005

\begin{tabular}{|c|c|c|c|c|c|}
\hline & & ISCED 0-2 & ISCED 3-4 & ISCED 5-6 & CLU-kvotient \\
\hline \multirow[t]{6}{*}{ Total } & EU-25 & -28 & -7 & 35 & 35 \\
\hline & Danmark & -22 & -10 & 31 & 31 \\
\hline & Finland & -19 & -2 & 21 & 21 \\
\hline & Island & -31 & -9 & 40 & 40 \\
\hline & Norge & -25 & -4 & 29 & 29 \\
\hline & Sverige & -23 & 5 & 18 & 23 \\
\hline \multirow[t]{6}{*}{ Mænd } & EU-25 & -28 & -6 & 34 & 34 \\
\hline & Danmark & -22 & -9 & 31 & 31 \\
\hline & Finland & -18 & -4 & 22 & 22 \\
\hline & Island & -32 & -10 & 42 & 42 \\
\hline & Norge & -22 & -5 & 28 & 28 \\
\hline & Sverige & -27 & 4 & 23 & 27 \\
\hline \multirow[t]{6}{*}{ Kvinder } & EU-25 & -27 & -9 & 36 & 36 \\
\hline & Danmark & -21 & -11 & 32 & 31 \\
\hline & Finland & -19 & 0 & 20 & 20 \\
\hline & Island & -30 & -7 & 37 & 37 \\
\hline & Norge & -28 & -2 & 30 & 30 \\
\hline & Sverige & -18 & 6 & 12 & 18 \\
\hline
\end{tabular}

Kilde: Beregnet ud fra tal fra Eurostat 2005.

For at skabe et samlet mål for et lands chancelighed i uddannelse er en kvotient blevet konstrueret. Denne kvotient er lavet som en fejlprocent fra chancelighed i uddannelse. Kvotienten går fra 0-100, hvor 0 repræsenterer absolut chancelighed og 100 repræsenterer en deterministisk sammenhæng mellem forældres baggrund og børnenes uddannelse, dvs. 100 pct. social arv, hvor individuelle forskelle ikke spiller nogen rolle.

Tabellen viser, at den sociale uddannelsesmobilitet varierer en del landene imellem. EU-25 har en score på 35. Norden klarer sig noget bedre i forhold til at sikre chancelighed i uddannelse. Norden har en gennemsnitlig score på 26. Dette forudsætter dog, at man ser bort fra Island, der har en ret høj score på 40, hvilket er endnu højere end EU25. Særligt Finland og Sverige klarer sig særdeles godt i sikring af chancelighed i rekruttering til de videregående uddannelser. Disse lande har scorer på hhv. 21 og 23, hvilket er markant bedre end Danmark og Norge, der scorer hhv. 31 og 29. Man kan sige, at Finland allerede lægger kimen til at bryde den sociale arv på Folkeskoleniveau, men forklaringen må findes et andet sted for Sverige, da de ikke ligger i top i forhold til inklusion i folkeskolen. 
Tabel 7.3 opsummerer de kønsmæssige forskelle angående social arv. Tallene giver ikke noget entydigt billede af, om det er mænd eller kvinder, der er bedst til at bryde den sociale arv. Om det er det ene eller det andet $k ø n$, der er mest påvirket af social arv varierer fra land til land og forskellene mellem kønnene indenfor et land er endvidere begrænsede. I tidligere forskningsundersøgelser har man fundet ud af, at mænd og kvinder i de højere klasser i højere grad ligner hinanden ift. social arv end i de lavere klasser, ${ }^{10}$ hvilket kan være forklaringen på det blandede billede.

Tabel 7.3: Kønsforskelle social arv

\begin{tabular}{lr}
\hline & Kønsforskelle mellem mænd og kvinder \\
\hline EU-25 & $-2,3$ \\
Danmark & $-0,3$ \\
Finland & 2,0 \\
Island & 5,2 \\
Norge & $-2,4$ \\
Sverige & 9,3 \\
\hline
\end{tabular}

Dog kan der identificeres nogle forskelle mellem kønnene i Island og i Sverige. Her er kvinderne bedre til at bryde den sociale arv med hhv. 5,2 og 9,3 procentpoint. I EU-25 og i Norge er mændene lidt bedre end kvinderne til at bryde den sociale arv end kvinderne. Og i Danmark er der stort set ingen forskel.

\subsection{Minoritetsbaggrund}

En af målsætningerne i EU's 2020 for højere uddannelser var bl.a. at øge rekrutteringen af studerende fra minoritetsgrupperne.

Tabel 7.4 Etniske mindretal på videregående uddannelser. Andele i pct. af BA studerende

\begin{tabular}{lccccc} 
& EU-15 & Danmark & Finland & Norge & Sverige \\
\hline $\begin{array}{l}\text { Ikke indvandrere } \\
\begin{array}{l}\text { 2. generations } \\
\text { indvandrere }\end{array}\end{array}$ & 84,9 & 86,2 & 96,0 & 87,1 & 71,9 \\
$\begin{array}{l}\text { 1. generations } \\
\text { indvandrer }\end{array}$ & 6,5 & 6,6 & 1,2 & 6,2 & 14,9 \\
Andre & 5,8 & 5,6 & 0,9 & 5,7 & 11,5 \\
& 2,8 & 1,6 & 1,9 & 1,0 & 1,7 \\
\hline
\end{tabular}

Kilde: Eurostudent. Mangler til EU-15: Belgien, Luxembourg, Holland, Frankrig, Italien, Grækenland, England. 



\section{Effekter af uddannelse}

I dette kapitel vil vi sætte uddannelse ind i en større perspektiverende kontekst ved at se på nogle af de mangeartede positive konsekvenser, der er forbundet med uddannelse - både for det enkelte individ og for samfundet.

For det første er uddannelse helt central for en positiv national$\varnothing$ konomisk udvikling eftersom uddannede borgere er mere produktive, hvilket naturligvis også betyder forbedrede økonomiske forhold for den enkelte.

Uddannelse er også afgørende set i et lighedsperspektiv, fordi et løft i uddannelsesniveau skaber basis for mere meritokratiske samfund, dvs. at samfundets statusposter i højere grad bliver besat med udgangspunkt i folks kvalifikationer. ${ }^{11}$ Dertil kommer en række andre forhold som lav befolkningstilvækst, bedre helbredstilstand samt længere levetid. Disse forhold er dog primært relevante, når man går fra et meget lavt uddannelsesniveau til at sikre universel adgang til primære og sekundære uddannelser. Denne overgang har de nordiske lande heldigvis passeret for længst.

Tabel 8.1 viser sammenhængen mellem uddannelsesniveau og hhv. valgdeltagelse, udførelse af frivilligt arbejde og tilfredshed med livet. Tre parametre som i tiltagende grad er kommet i fokus i de senere år efter, at man er blevet mere kritisk overfor BNP som velstandsmål. Der er ingen tvivl om, at uddannelse har en positiv effekt på vækst i BNP, men også i forhold til disse andre parametre har et højt uddannelsesniveau gunstige virkninger.

Tabellen er opdelt på uddannelsesniveau. Således giver tallene både et samlet billede af, hvordan de nordiske lande klarer sig og desuden kan man se, hvorvidt der er en positiv sammenhæng mellem uddannelsesniveau og hhv. valgdeltagelse, udførelse af frivilligt arbejde og tilfredshed med livet. 
Tabel 8.1: Sammenhæng mellem uddannelse og hhv. valgdeltagelse, deltagelse I frivilligt arbejde og tilfredshed med livet. 2011

\begin{tabular}{|c|c|c|c|c|c|c|c|c|c|c|c|c|}
\hline \multirow[b]{2}{*}{$\begin{array}{l}\text { Højest afsluttede } \\
\text { uddannelse }\end{array}$} & \multicolumn{4}{|c|}{$\begin{array}{l}\text { Valgdeltagelse } \\
\text { stemmeprocent }\end{array}$} & \multicolumn{4}{|c|}{$\begin{array}{l}\text { Andel der udfører } \\
\text { frivilligt arbejde }\end{array}$} & \multicolumn{4}{|c|}{$\begin{array}{c}\text { Andel som er } \\
\text { tilfredse med livet }\end{array}$} \\
\hline & $\begin{array}{l}\text { Videre- } \\
\text { gående }\end{array}$ & $\begin{array}{l}\text { Ungdoms- } \\
\text { uddannelse }\end{array}$ & Folkeskole & Total & $\begin{array}{l}\text { Videregå- } \\
\text { ende }\end{array}$ & $\begin{array}{l}\text { Ungdoms- } \\
\text { uddannelse }\end{array}$ & Folkeskole & Total & $\begin{array}{l}\text { Videre- } \\
\text { gående }\end{array}$ & $\begin{array}{l}\text { Ungdoms- } \\
\text { uddannelse }\end{array}$ & Folkeskole & Total \\
\hline Danmark & 97,8 & 95,7 & 89,6 & 94,4 & 29,8 & 27,8 & 20,2 & 25,9 & 95,0 & 93,9 & 92,7 & 93,9 \\
\hline Finland & 90,3 & 77,4 & 76,1 & 81,3 & 12,1 & 11,4 & 13,8 & 12,4 & 90,4 & 88,4 & 83,0 & 87,3 \\
\hline Norge & 93,3 & 84,5 & 76,8 & 84,9 & 30,4 & 28,3 & 11,2 & 23,3 & 87,0 & 84,4 & 75,3 & 82,2 \\
\hline Sverige & 97,1 & 90,9 & 86,2 & 91,4 & 24,0 & 21,4 & 22,0 & 22,5 & 86,4 & 85,3 & 82,7 & 84,8 \\
\hline OECD & 87,2 & 79,4 & 74,0 & 80,2 & 20,0 & 14,9 & 10,8 & 15,2 & 75,5 & 67,3 & 57,9 & 66,9 \\
\hline EU-21 & 88,4 & 80,8 & 75,3 & 81,5 & 19,8 & 14,4 & 11,2 & 15,1 & 74,4 & 64,8 & 55,8 & 65,0 \\
\hline
\end{tabular}

Kilde: Education at a Glance 2011. *Island har ikke tilgængelige tal på disse parametre. 
Figur 8.1 illustrerer, hvorledes valgdeltagelsen fordeler sig ift. uddannelsesniveau. Alle de nordiske lande på nær Finland har en højere valgdeltagelse end EU-21 og OECD. Danmark og Sverige har de højeste deltagelsesprocenter. Inden for hvert land er der klare positive sammenhænge mellem uddannelse og valgdeltagelse, således at valgdeltagelsen stiger med højere uddannelsestrin.

Figur 8.1: Valgdeltagelse stemmeprocent

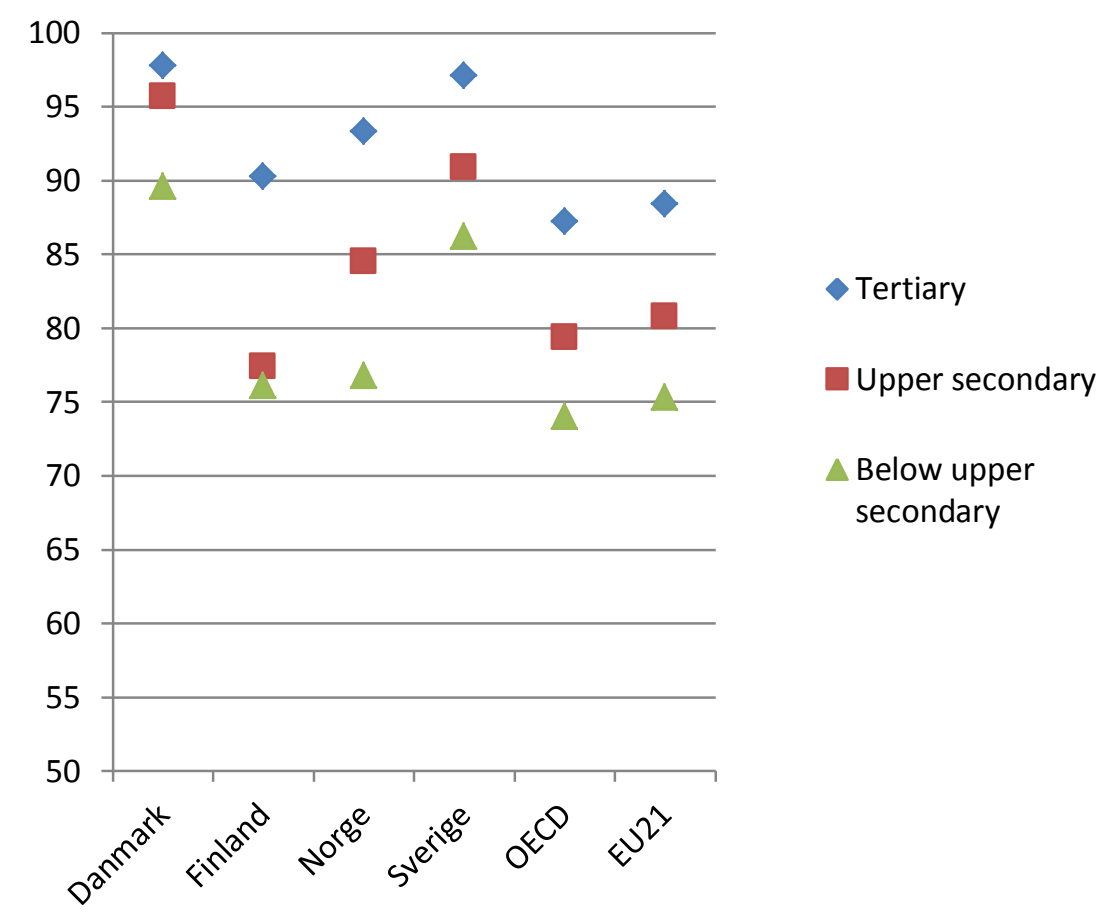

Kilde: Education at a Glance 2011.

Figur 8.2 illustrerer hvorledes deltagelse i frivilligt arbejde fordeler sig på uddannelsesniveauerne. Også på dette parameter er der en positiv sammenhæng, således at det særligt er folk med videregående uddannelser, der deltager i frivilligt arbejde. Danmark, Norge og Sverige ligger alle højt, dog er fordelingerne mellem uddannelsesniveauerne forskellige. 
Figur 8.2: Andel der udfører frivilligt arbejde (pct.)

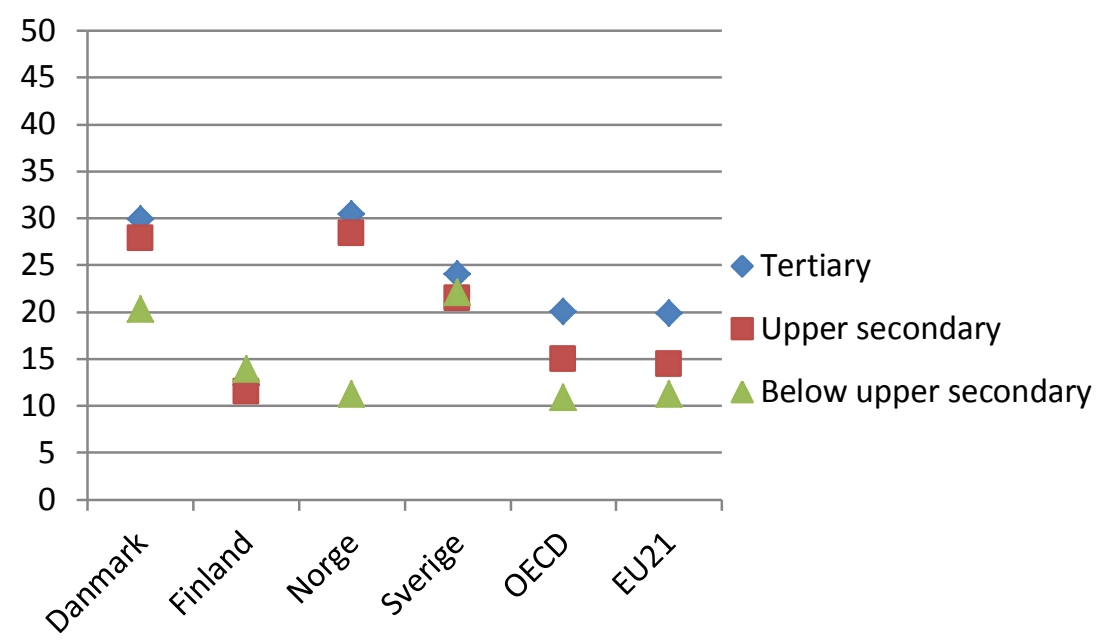

Kilde: Education at a Glance 2011.

I Danmark og Norge halter dem med folkeskole som højeste uddannelse væsentlig efter dem med ungdomsuddannelser. I Sverige derimod er der ikke nogen særlig sammenhæng mellem uddannelse og deltagelse i frivilligt arbejde. En sådan sammenhæng findes heller ikke i Finland, der derudover adskiller sig ved at have et markant lavere aktivitetsniveau i frivilligt arbejde. Der er naturligvis mange ting, der spiller ind ift. aktivt foreningsliv, dog ses der en rimelig klar tendens til, at de ekstra ressourcer man opnår i forbindelse med at tage en uddannelse også udmønter sig i deltagelse i frivilligt arbejde.

\section{Figur 8.3: Tilfredshed med livet}

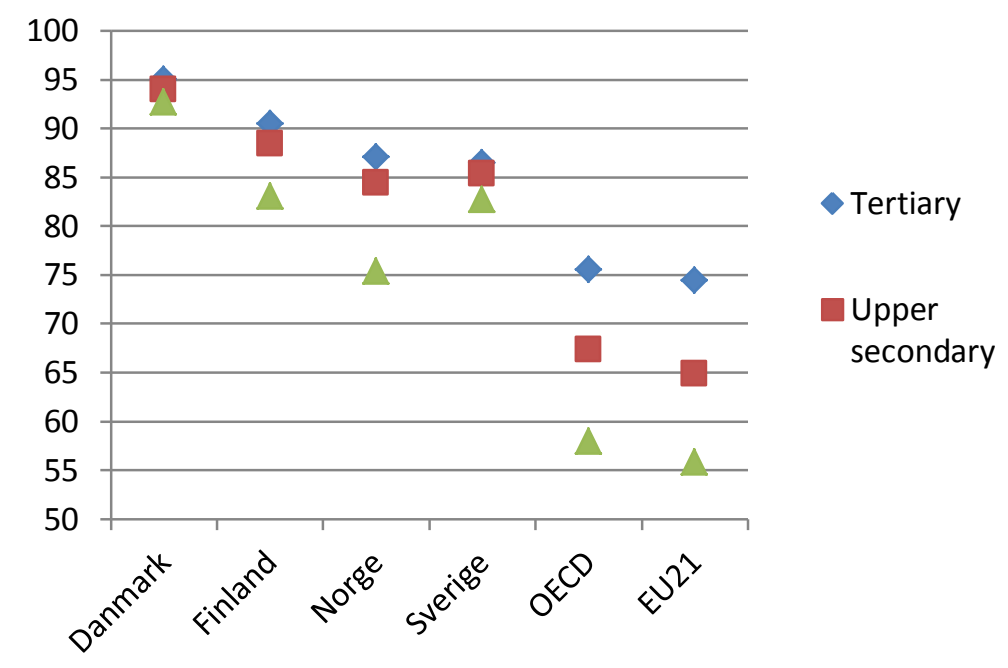

Kilde: Education at a Glance 2011. 
En meget upåagtet OECD-tabel fortæller i en nøddeskal om de positive konsekvenser, der er forbundet med de høje uddannelsesniveauer i Norden.

Med hensyn til valgdeltagelse og tilfredshed med livet ligger de højt uddannede i de nordiske lande langt over OECD og EU-gennemsnittet. Men på frivilligt arbejde er der større forskelle. Her ligger Danmark, Norge og Sverige over gennemsnittet for OECD og EU, mens Finland har en lav andel.

\begin{tabular}{|c|c|c|c|}
\hline & $\begin{array}{r}\text { Valgdeltagelse } \\
\text { stemmeprocent }\end{array}$ & $\begin{array}{l}\text { Andel der udfører } \\
\text { frivilligt arbejde }\end{array}$ & $\begin{array}{l}\text { Andel som er } \\
\text { tilfredse med livet }\end{array}$ \\
\hline Danmark & 97,8 & 29,8 & 95 \\
\hline Finland & 90,3 & 12,1 & 90,4 \\
\hline Island & - & - & - \\
\hline Norge & 93,3 & 30,4 & 87 \\
\hline Sverige & 97,1 & 24 & 86,4 \\
\hline $\mathrm{OECD}$ & 87,2 & 20 & 75,5 \\
\hline EU-21 & 88,4 & 19,8 & 74,4 \\
\hline
\end{tabular}

Kilde: OECD's Education at a Glance 2011.

Det kan bemærkes, at også lavere uddannede i de nordiske lande ligger højere end de øvrige lande. Der er både nationale og uddannelsesmæssige forskelle. Uddannelse betaler sig, ikke kun med hensyn til økonomisk afkast, men også på mere bløde værdier. Men i de nordiske lande er der også mere generelle samfundsmæssige værdier, som giver $h ø j$ score. ${ }^{12}$

12 http://www.amacad.org/publications/monographs/Ubase.pdf 



\section{Udgifter til uddannelse}

Uddannelsesudgifter er ikke med i den oprindelige beskrivelse af dette projekt, men vi har valgt kort at medtage ressourceproblematikken, fordi de nordiske lande adskiller sig på dette område. Andelen af bruttonationalproduktet som bruges på højere uddannelse er således højere i alle de nordiske lande end EU-27 gennemsnittet.

Blandt de nordiske lande ligger Danmark og Norge højest, mens Island ligger lavest, dog over EU-27 gennemsnittet. Sidstnævnte hænger sammen med, at Island sender mange unge på universitetsuddannelse i udlandet, særligt til Danmark og andre nordiske lande.

Figur 9.1: Procentdel af BNP brugt på højere uddannelse (ISCED 5-6)

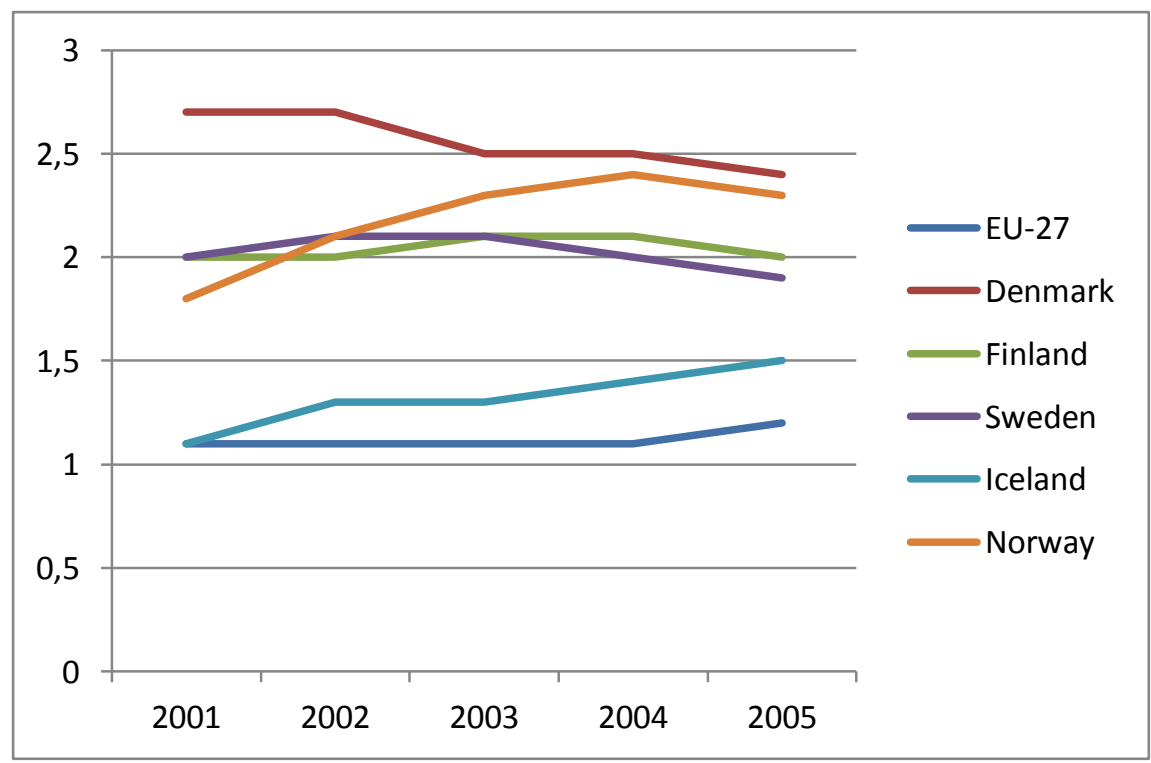

Den årlige udgift pr. student (årselev) er i nordiske lande ligger over både OECD-gennemsnittet og EU-21-gennemsnittet for højere uddannelser og alle uddannelser. Det er kun Island, der har lavere udgiftsniveau per årselev. Island driver fx. et meget billigt universitet. Sverige har den højeste udgift for højere uddannelser, mens Norge har den højeste udgift for alle uddannelser. Udgifterne for højere uddannelser har OECD beregnet som udgiften pr. årselev på institutioner, hvis kerneservice er at udbyde højere uddannelser - eksempelvist et universitet. 
Tabel 9.1: Årlig udgift pr. student til hhv. højere uddannelsesinstitutioner og alle institutioner inkl. R\&D. USD 2008

\begin{tabular}{lrr}
\hline & $\begin{array}{r}\text { Udgift pr student } \\
\text { på højere uddannelser (videregående) }\end{array}$ & $\begin{array}{r}\text { Udgift pr student } \\
\text { på alle uddannelser }\end{array}$ \\
\hline Danmark & 17.634 & 11.788 \\
Finland & 15.402 & 9.463 \\
Island & 10.429 & 9.873 \\
Norge & 18.942 & 13.285 \\
Sverige & 20.014 & 11.162 \\
OECD-gennemsnit & 13.717 & 8.831 \\
EU-21-gennemsnit & 12.958 & 8.702 \\
\hline
\end{tabular}

Kilde: OECD Education at a Glance 2011 s. 219. Der bruges en USD equivalent konverteret til købekraftspariteter (PPP).

Figur 9.2 nedenfor viser en kraftig udvikling i udgifterne til højere uddannelser i EU-27 i forhold til de totale offentlige udgifter. Den samme udvikling ses i Norge som har satset meget på de højere uddannelser i de seneste år - se også Figur ovenfor. De danske udgifter ligger nogenlunde stabilt, men udgifterne i Finland, Sverige og Island er svagt stigende.

Figur 9.2. Totale offentlige udgifter til højere uddannelser (ISCED 5-6). Indeksering af udgifter i mio. EUR PPS (løbende priser)

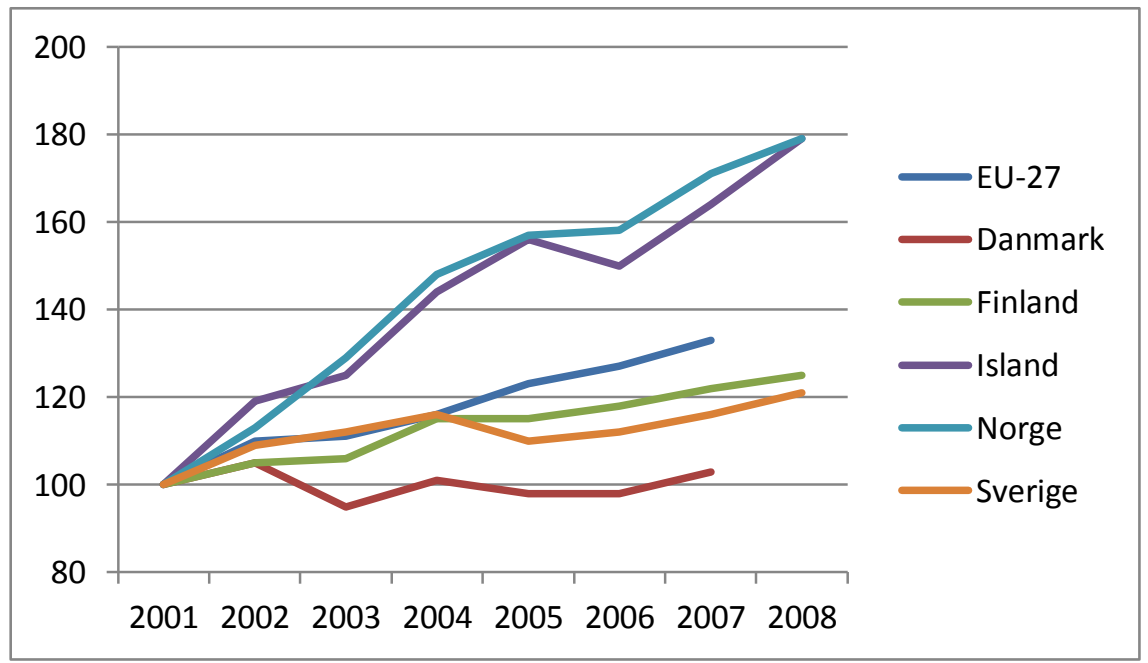




\section{Fra højere uddannelse til arbejdsmarked}

Generelt har de højere uddannelser i de nordiske lande højere beskæftigelsesfrekvenser end OECD- og EU-gennemsnittet. De norske videregående uddannede har de højeste beskæftigelsesfrekvenser, mens Finland ligger tættere på OECD og EU-gennemsnittet. Med den økonomiske krise i det sydlige Europa forværret efter 2009 har de nordiske lande yderligere øget deres forspring. 
Tabel 10.1: Udviklingen i beskæftigelsesfrekvenser for den voksne befolkning med tertiær uddannelse

\begin{tabular}{|c|c|c|c|c|c|c|c|c|c|c|c|c|c|c|}
\hline & 1997 & 1998 & 1999 & 2000 & 2001 & 2002 & 2003 & 2004 & 2005 & 2006 & 2007 & 2008 & 2009 & 2010 \\
\hline Danmark & & 87,5 & 87,9 & 88,6 & 87,2 & 86,0 & 85,2 & 85,5 & 86,4 & 87,4 & 87,2 & 88,5 & 86,8 & 85,7 \\
\hline Finland & 82,6 & 83,2 & 84,7 & 84,4 & 85,1 & 85,1 & 85,0 & 84,2 & 84,1 & 85,0 & 85,2 & 85,6 & 84,4 & 84,1 \\
\hline Island & 94,6 & 94,7 & 95,1 & 95,0 & 94,7 & 95,4 & 92,7 & 92,0 & 92,0 & 92,0 & 92,2 & 91,0 & 88,3 & 89,1 \\
\hline Norge & 90,2 & 90,2 & 90,2 & 89,9 & 89,6 & 89,5 & 88,8 & 89,3 & 88,8 & 89,2 & 90,4 & 90,6 & 90,2 & 90,4 \\
\hline Sverige & 85,0 & 85,5 & 85,6 & 86,7 & 86,9 & 86,5 & 85,8 & 85,4 & 87,3 & 87,3 & 88,6 & 89,2 & 88,1 & 88,1 \\
\hline OECD & 84,2 & 84,4 & 84,5 & 84,7 & 84,7 & 84,2 & 83,7 & 83,6 & 84,0 & 84,5 & 84,5 & 84,6 & 83,6 & 83,1 \\
\hline EU-21 & 83,8 & 84,5 & 84,9 & 85,1 & 85,2 & 84,7 & 84,3 & 84,2 & 84,6 & 85,1 & 85,3 & 85,5 & 84,4 & 83,6 \\
\hline
\end{tabular}

Kilde: Education at a Glance 2011, tabel A7.3a.

Tabel 10.2: Udviklingen i ledighedsprocenter for højere uddannede I den voksne befolkning 25-64 årige

\begin{tabular}{|c|c|c|c|c|c|c|c|c|c|c|c|c|c|c|}
\hline & 1997 & 1998 & 1999 & 2000 & 2001 & 2002 & 2003 & 2004 & 2005 & 2006 & 2007 & 2008 & 2009 & 2010 \\
\hline Danmark & - & 3,3 & 3,0 & 3,0 & 3,6 & 3,9 & 4,7 & 4,4 & 3,7 & 3,2 & 3,0 & 2,2 & 3,7 & 4,6 \\
\hline Finland & 6,5 & 5,8 & 4,7 & 4,7 & 4,4 & 4,5 & 4,1 & 4,5 & 4,4 & 3,7 & 3,6 & 3,3 & 4,0 & 4,4 \\
\hline Island & - & - & - & - & - & - & - & - & - & - & - & - & 3,9 & 3,5 \\
\hline Norge & 1,7 & 1,5 & 1,4 & 1,9 & 1,7 & 2,1 & 2,5 & 2,4 & 2,1 & 1,8 & 1,4 & 1,3 & 1,4 & 1,6 \\
\hline Sverige & 5,2 & 4,4 & 3,9 & 3,0 & 2,6 & 3,0 & 3,9 & 4,3 & 4,5 & 4,2 & 3,4 & 3,3 & 4,3 & 4,3 \\
\hline OECD & 4,1 & 4,0 & 3,8 & 3,5 & 3,3 & 3,8 & 4,1 & 4,1 & 3,9 & 3,5 & 3,4 & 3,3 & 4,4 & 4,7 \\
\hline EU-21 & 4,7 & 4,4 & 4,1 & 3,8 & 3,5 & 3,8 & 4,2 & 4,2 & 4,1 & 3,7 & 3,4 & 3,2 & 4,3 & 4,9 \\
\hline
\end{tabular}

Kilde: Education at a Glance 2011, Tabel A7.4a. 
Ledigheden for de højtuddannede var indtil 2009 relativt beskeden uden store forskelle på de nordiske lande og OECD og EU-gennemsnittet. Forskellene er lidt mindre end for beskæftigelsesfrekvensernes vedkommende. Det skyldes forskelle i andelen helt uden for arbejdsmarkedet.

Nedenstående tabel 10.3 viser, at der er en vis forskel på ledighedsprocenten for de højere uddannede og for alle med en uddannelse. Kønsforskellene for de højere uddannede viser, at kvinderne har lavere ledighed i de nordiske lande bortset fra Finland. Det omvendte gælder for højt uddannede kvinder i EU og OECD som ligger lidt højere end mændene. For alle uddannede har mændene den højeste ledighed. Det gælder også Finland og OECD som helhed.

Tabel 10.3: Ledighedsprocenter 2009. Kønsopdelt

\begin{tabular}{lrrrr} 
& \multicolumn{2}{c}{ Tertiaer 5A } & \multicolumn{2}{c}{ Alle uddannelser } \\
& Mænd & Kvinder & Mænd & Kvinder \\
\hline Danmark & 3,8 & 3,5 & 5,6 & 4,4 \\
Finland & 3,6 & 4,7 & 7 & 6 \\
Island & - & - & 6,7 & 4,4 \\
Norge & 1,5 & 1,5 & 2,5 & 1,6 \\
Sverige & 4,2 & 3,7 & 6,3 & 5,6 \\
OECD & 4,1 & 4,4 & 6,9 & 6,6 \\
EU-21 & 3,9 & 4,4 & 7,4 & 7,4 \\
\hline
\end{tabular}

Kilde: Education at a Glance.

I forbindelse med ovenstående opgørelser over beskæftigelses- og ledighedsfrekvenser er det relevant at inddrage resultater fra tidligere norske og svenske undersøgelser, om nyuddannedes tilknytning og tilpasning til arbejdsmarkedet.

I den norske undersøgelse "kandidatundersøkelsen 2009" er tæt på alle, der er blevet kandidater i foråret 2009 inddraget. I undersøgelsen skelner man blandt andet mellem nyuddannede kandidater i arbejdsstyrken og såkaldt mistilpassede nyuddannede kandidater. Mistilpassede kandidater er defineret ved arbejdsløse, underbeskæftigede (deltid) og irrelevant arbejde. Af 2009-kandidaterne i Norge kunne 17,1 pct. karakteriseres som mistilpassede.

Nedenstående figur viser hvilke grupper, der udgør de mistilpassede. Den klart største grund til at ende i kategorien mistilpasset er arbejdsløshed. Over en tredjedel af de mistilpassede er således arbejdsløse. Også underbeskæftigede samt nyuddannede kandidater med irrelevant arbejde pga. svære forhold på arbejdsmarkedet fylder væsentligt mere end gruppen af nyuddannede kandidater med irrelevant arbejde af andre grunde end arbejdsmarkedet. 


\section{Figur 10.1}

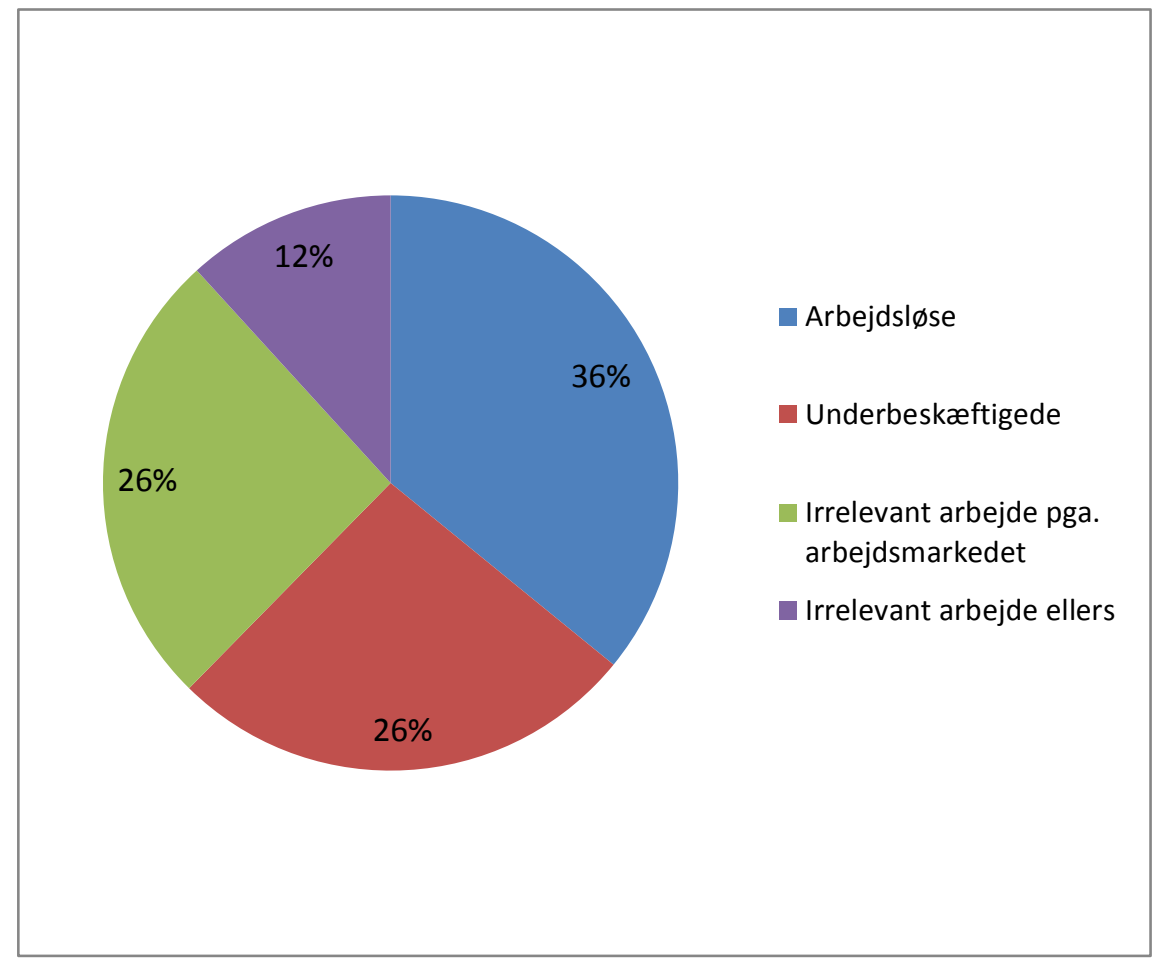

Kilde: "Kandidatundersøkelsen 2009".

I tabellen nedenfor er andelen af mistilpassede nyuddannede kandidater fordelt på studieretning. Det er særligt de humanistiske fag, der i 2009 producerede mange mistilpassede kandidater - 28 pct. Også samfundsfag har en høj grad af mistilpassede kandidater. For både de humanistiske fag samt for samfundsfag gælder det, at arbejdsløshed, underbeskæftigelse og irrelevant arbejde pga. arbejdsmarkedet er stort set lige store problemer for mistilpassede kandidater. Både for lærere/pædagoger og økonomiskadministrative fag er der en meget lille del af mistilpassede kandidater. 
Figur 10.2

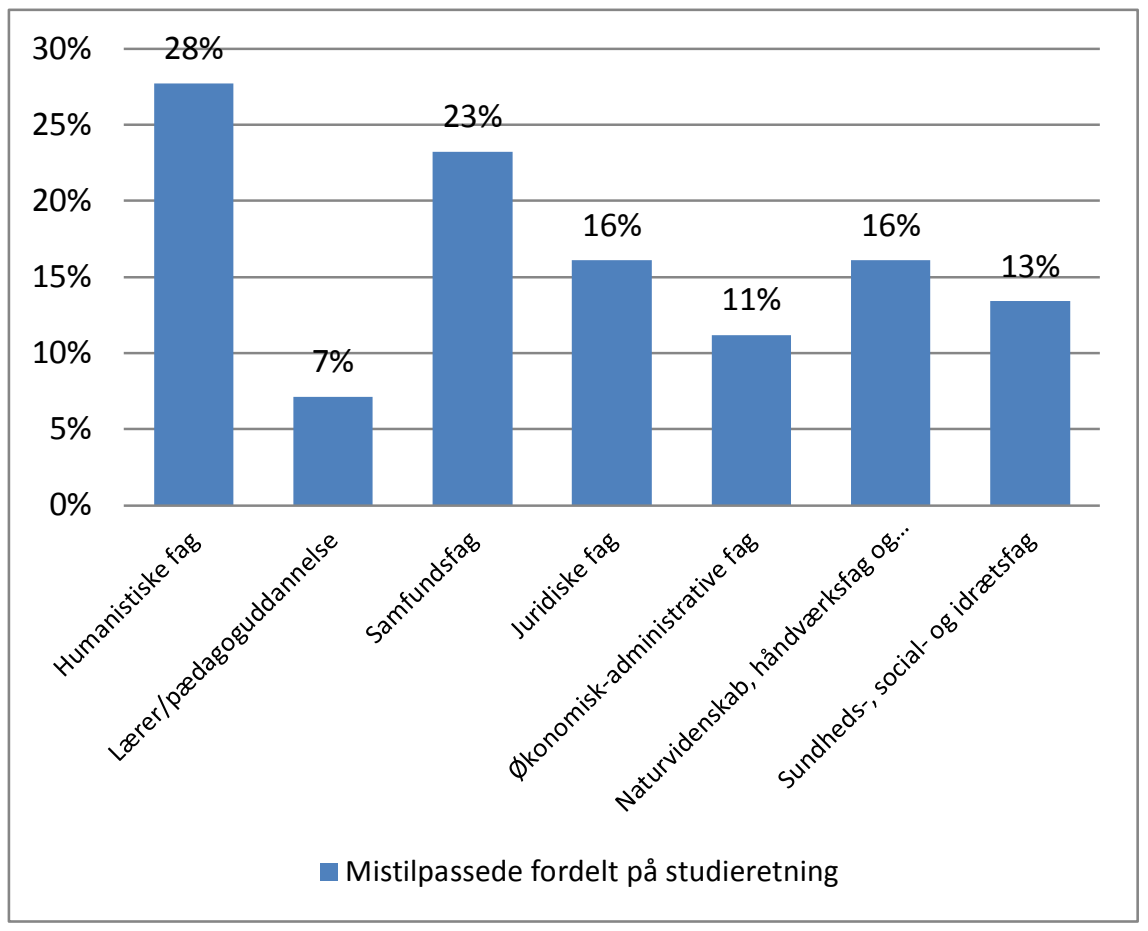

Kilde: "Kandidatundersøkelsen 2009".

Det samme billede som figuren ovenfor viser, går igen i en svensk undersøgelse fra 2009 - Högutbildades arbetsmarknad - hvor man har undersøgt kandidater, der er blevet færdige i foråret 2009. Det er i denne undersøgelse også klart de humanistiske fag, der ikke ender med at få arbejde inden for det område, man er kandidat inden for. I 2009-årgangen var det op i mod 50 pct. der arbejdede med noget andet end deres eksamen lagde op til. I Sverige er det især de tekniske fag, der har en høj overensstemmelse mellem arbejde og eksamen. Undersøgelsen i Sverige peger på forskellige grunde til mismatch mellem arbejde og eksamen. Den vigtigste grund er således, at det i det hele taget er svært at finde et arbejde. En anden er at det er svært at finde et arbejde tæt på, der hvor man bor. Dette er en væsentlig mismatch faktor (især for kvinder).

Nedenstående tabel 10.4 og figurerne 10.3-10.4 viser forskellen i udbuddet og efterspørgslen af akademisk arbejdskraft i perioden 2008-10.

Ubalancerne mellem de forskellige faggrupper I kriseåret 2009 vises i tabel 10.4. I Danmark er billedet vendt helt efter 2009 og mangel er erstattet af ledighed i 2012. 
Tabel 10.4: Mismatch. Forskel mellem udbud og efterspørgsel for hovedgrupper i de nordiske lande. 2009

\begin{tabular}{lrrrrr}
\hline & Danmark & Norge & Sverige & Finland & Total \\
\hline Humanistisk mv. & -200 & -500 & 1.350 & 1.500 & 2.150 \\
Naturvidenskabelig & -250 & -1.000 & 2.150 & 1.250 & 2.150 \\
Samfundsvidenskabelig & -650 & -750 & 5.150 & 1.800 & 5.550 \\
Teknisk & -200 & - & 2.550 & 550 & 2.900 \\
Sundhed & -200 & -250 & 950 & 25 & 525 \\
\hline
\end{tabular}

Kilder: Estimat baseret på de statistiske bureauer, arbejdsmarkedsbarometer i Sverige, Arbejdsmarkedsstyrelsen i Danmark, NIFU m.fl.

Mens der var rimelig overordnet balance i 2008, var billedet i 2010 vendt til et betydeligt overskud.

\section{Figur 10.3: Mismatch af akademisk arbejdskraft i Norden, 2008}

Mismatches - Nordic labour force for academics, 2008 Shortage, balances and surplus

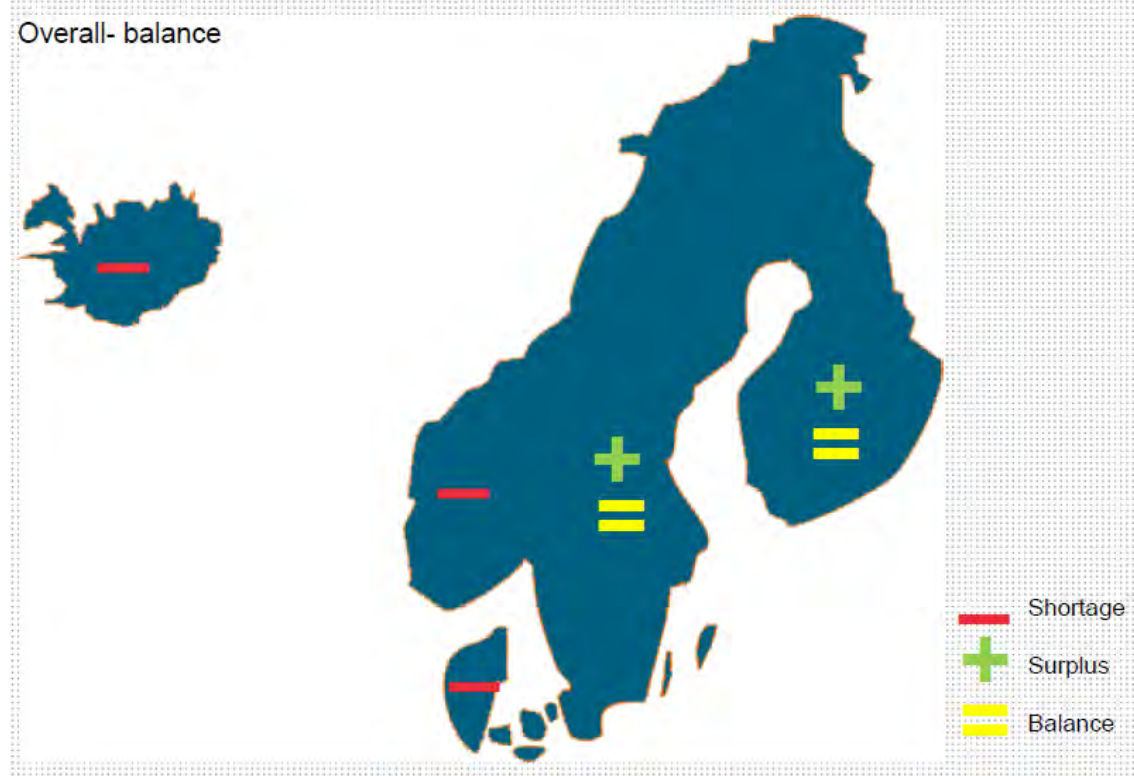


Figur 10.4: Mismatch af akademisk arbejdskraft i Norden, 2010.

Mismatches - Nordic labour force for academics, 2010

Shortage, balances and surplus

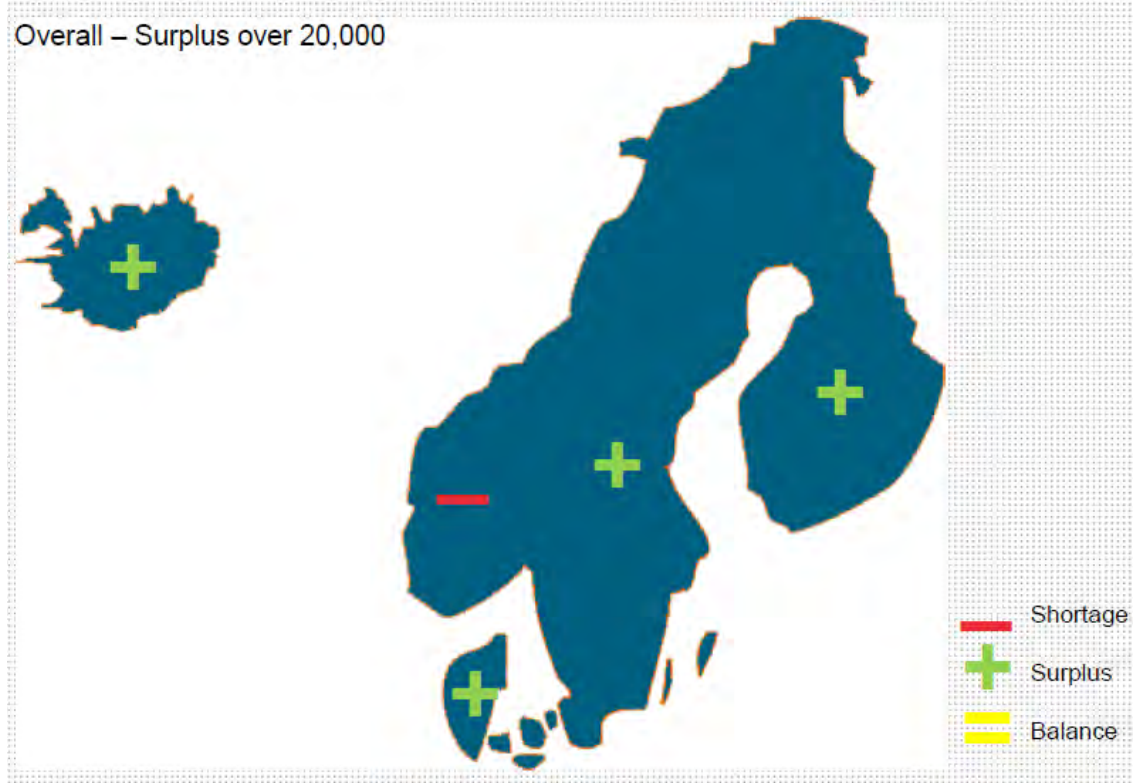





\section{Prognoser}

Der kan forventes betydelig mangel på højere uddannet arbejdskraft i Norden trods den aktuelle ledighed blandt højtuddannede i alle nordiske lande bortset fra Norge.

Lægger man skønnene for 2030 sammen er det en betydelig mangel, man kan forudse.

Der er dog betydelige forskelle mellem de nordiske lande. Svenske fremskrivninger er mindre optimistiske end danske og norske. Tidsperspektivet for prognoserne er meget vigtigt.

Først efter 2020 forventes manglerne at sætte ind

Figur 11.1: Mismatch af akademisk arbejdskraft i Norden, 2030

Mismatches - nordiske arbejdsmarked for akademikere, 2030 Mangler, balancer og overskud

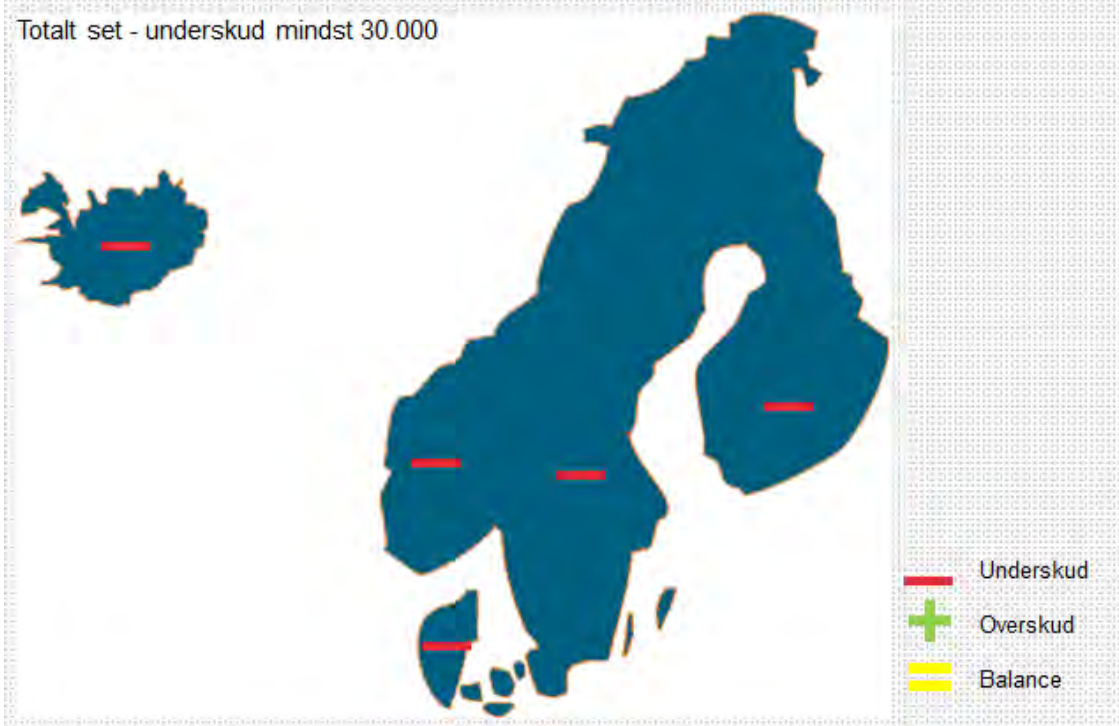


Nedenstående tabel er en svensk prognose for efterspørgslen af folk med en bestemt uddannelse i forhold til udbuddet af folk med denne uddannelse i år 2030. Der er især tre områder, hvor der vil mangle færdiguddannede i 2030. Det ene er grundskolen og gymnasiet, hvor der vil være et meget større udbud end efterspørgsel i 2030 - mellem 100.000 og 200.000. De to andre områder, hvor der er større udbud end efterspørgsel i 2030, som er mere relevante for denne rapports fokus på højere uddannelse, er de humanistiske uddannelser samt samfundsvidenskab, jura, handel og administration. For naturvidenskab, tekniske fag og land- og skovbrug er der lidt større udbud i forhold til efterspørgsel. Generelt ser fremtids- og jobudsigterne for de kandidater fra videregående uddannelser i Sverige ikke kun positive ud. Dog er der mangel på sundhedsuddannede. Her forventes en meget større efterspørgsel end udbud i 2030.

\section{Figur 11.2}

Tillgång och efterfrågan på arbetskraft år 2030

Fördelning efter utbildningsinriktning (samtliga utbildningsnivảer)

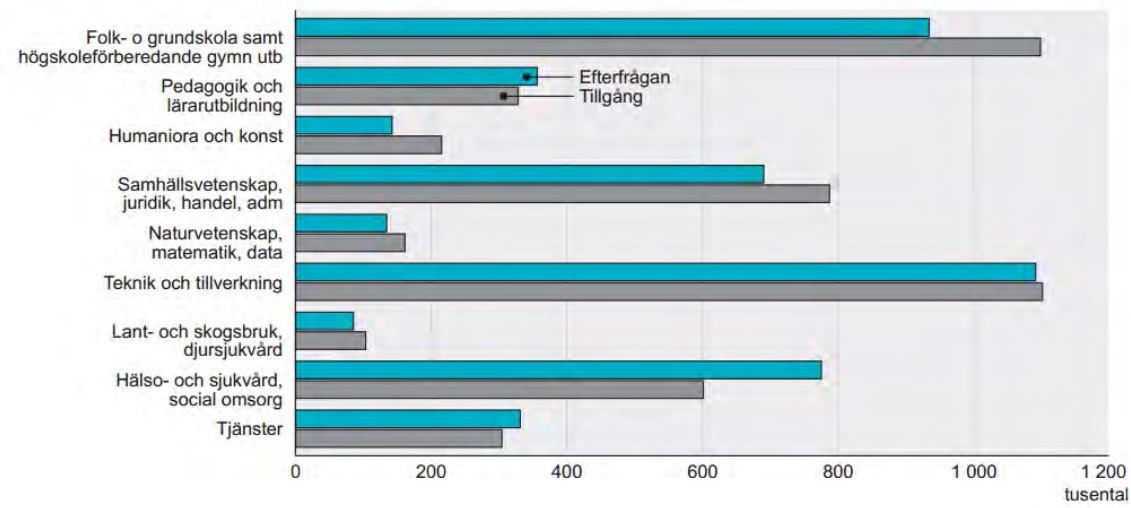

Kilde: "Trends and Forecasts 2012 population, education and labour market in Sweden - outlook to year 2030" p.7. Statistics Sweden (2012). 
Tal fra Norge ("Tilbud og etterspørsel etter arbeidskraft etter utdanning, 1986-2025”) viser, at der i Norge i 2025 vil være større ovensstemmelse mellem udbud og efterspørgsel af akademisk arbejdskraft end der generelt set er i Sverige. I Norge er problemet - ligesom i Sverige - at der er for mange med en grundskoleuddannelse. På dette uddannelsesniveau er udbuddet således væsentligt større end efterspørgslen.

Nedenstående tabel viser en nyere dansk fremskrivning.

\begin{tabular}{|c|c|c|c|c|c|}
\hline & 2015 & 2020 & 2025 & 2030 & \\
\hline Samfundsfaglige & -1.000 & -5.000 & -10.000 & -10.000 & \multirow{6}{*}{$\begin{array}{l}\text { Fremskrivning af ubalan- } \\
\text { cer mellem udbud og } \\
\text { efterspørgsel efter } \\
\text { universiteteskandidater } \\
\text { 2015-2030. Scenarium } \\
\text { med accelererede } \\
\text { kvalifikationskrav }\end{array}$} \\
\hline Humanistiske/kunstneriske & 2.000 & 800 & 400 & 400 & \\
\hline Tekniske & -1.800 & -5.600 & -11.900 & -11.900 & \\
\hline Natur/veterinær & -1.000 & -2.500 & -6.000 & -6.000 & \\
\hline Sundhedsvidenskabelige & -2.200 & -3.100 & -3.300 & -3.300 & \\
\hline I alt & -4.000 & -15.400 & -30.800 & -30.800 & \\
\hline
\end{tabular}

Kilde: "Fremtiden kalder. Uddanner vi nok?". Dansk Industri (2010). 



\section{Summary of results}

The report gives comparative statistics on education among the Nordic countries and forms the basis for a Nordic Education at Glance. Furthermore, the report supports the University Profile Project (CHEPS) in a number of areas such as:

- Participation rates, completion rates, and employment rates

- Social background factors.

- Higher level of detail in data and prospects for the higher education in the Nordic countries.

The report provides an opportunity to draw some conclusions about higher education in the Nordic countries. The main ones are:

- Graduation rates in the Nordic countries is steadily increasing and is considerably above both the OECD and EU averages, although there are relatively significant differences between the Nordic countries.

- Students in the Nordic countries have continuously spent relatively long time on their study, but it is declining. Completion rates are close to the OECD and EU averages.

- The Nordic countries have an increasing inflow of foreign fulldegree students.

- The production of PhD's is increasing throughout the Region, albeit slightly declining in Finland and especially Sweden, which has previously been the leader, while Denmark now has high production figures.

- Women in the Nordic countries are (increasingly) better to obtain education than men are.

- The Nordic countries are better to diminish the impact of social background than the EU-25, especially for men. Nordic countries have inclusive school systems with good conditions for creating training and maintenance-related equality of opportunity. There are greater educational "opportunity equality" than in the EU-25. Iceland, however, lags behind. 
- In the Nordic countries, higher educated have lower unemployment rates than in the EU. Furthermore, the wage structure is very egalitarian.

- Despite current unemployment among highly educated in the Nordic countries there is prospect of shortages in the longer term, particularly in Norway.

- The high level of education in the Nordic countries has a number of side effects such as stronger voting participation, more volunteering and higher life satisfaction. 


\section{Referencer}

Aamodt, Per Olaf; Wiers-Jenssen, Jannecke \& Stensaker, Bjørn (2012). Kvalitetskriterier i høyere utdanning.Bakgrunnsnotat for etablering av en norsk informasjonsportal. NIFU-rapport. Norsk institutt for studier av innovasjon, forskning og utdanning. Oslo.

Arnesen, Clara Åse (2010). Kandidatundersøkelsen 2009. Hovedresultater. NIFUrapport. Norsk institutt for studier av innovasjon, forskning og utdanning. Oslo.

Arnesen, Clara Åse (2012). Profesjonsutdannedes overgang fra utdanning til arbeid, Arbeidsmarkedstilpasning, yrkesverdier og tilfedshet med arbeid og utdanning. NIFUrapport. Norsk institutt for studier av innovasjon, forskning og utdanning. Oslo.

Arnesen, Clara Åse \& Waagene, Erica (2009). Bachelorgraden fra universitet - en selvstendig grad, eller delmål I et lengre utdanningsløp? NIFU-rapport. Norsk institutt for studier av innovasjon, forskning og utdanning. Oslo.

Arnsen, Clara Åse (2010); "Kandidatundersøkelsen 2009 - hovedresultater". Oslo

Arnesen, Clara Åse; Opheim, Vibeke; Næss, Terje; Aamodt, Per Olaf \& Henaug, Inger (2009). Alder ved yrkesstart, sysselsettingsmønstre og yrkesaktivitet. En oversikt over utvalgte grupper med høyere utdanning. NIFU-rapport. Norsk institutt for studier av innovasjon, forskning og utdanning. Oslo.

European Commission (2011) Education and Training in a smart, sustainable and inclu-sive Europe. Brussels.

Eurostat database:

http://epp.eurostat.ec.europa.eu/portal/page/portal/statistics/search_database

Eurostudent database: http://www.eurostudent.eu/

Frølich, Nicoline; Waagene, Erica \& Aamodt, Per Olaf (2010). Gamle spillere - nye regler. Samspiller mellom efterspørsel og tilbud av høyere utdanning. Søkning til høyere utdanning og lærestedenes utdanningsprofil etter Kvalitetsreformen. NIFUrapport. Norsk institutt for studier av innovasjon, forskning og utdanning. Oslo.

Frølich, Nicoline; Waagene, Erica \& Aamodt, Per Olaf (2010). Stor stabilitet I søkningen til høyere utdanning etter 2003. Forskningspolitikk 42010 s. 14-15.

Frøseth, Mari Wigum; Hovdhaugen, Elisabeth; Høst, Håkon \& Vibe, Nils (2010). En, to... tre? Den vanskelige overgangen. Evaluering av Kunnskapsløftet. Fra andre til tredje år i videregående opplæring. NIFU-rapport. Norsk institutt for studier av innovasjon, forskning og utdanning. Oslo.

Hovdhaugen, Elisabeth; Frøseth, Mari Wigum \& Aamodt, Per Olaf (2010). Fullføring og frafall på hovedfag og mastergrad. Sammenligning av kullene som begynte i 1999 og 2003. NIFU STEP. Norsk institutt for studier av innovasjon, forskning og utdanning. Oslo.

Høgskoleverket rapport 2012: 2 R: Studenternes studiemoenster och totala studietider. Sveriges officiella statistik (UF 20 SM 1103: Universiteter og hogskolor.

"Högutbildades arbetsmarknad - arbete inom examsområdet tre år efter examen".

Krogstrup, Hanne Katrine. (2008) Idégruppen for at bryde den sociale arv på universitetsuddannelserne. Hvordan øges den sociale uddannelsesmobilitet på universitetsuddannelserne? - Anbefalinger til videnskabsministeren.

Munk, Martin D. \& Mattsson, Cathrine (2008) Social uddannelsesmobilitet på kandidat og forskeruddannelser, SFI - Det nationale forskningscenter for velfærd, København. NIFU-rapport. Norsk institutt for studier av innovasjon, forskning og utdanning. Oslo. OECD (2010), Education at a Glance 2011: OEDC Indicators, OECD Publishing. OECD (2011), Education at a Glance 2011: OEDC Indicators, OECD Publishing. 
OECD (2012), Education at a Glance 2011: OEDC Indicators, OECD Publishing

Kyvik, Svein \& Olsen, Terje Bruen (2009). Gjennomstrømning i doktorgradsutdannigen. NIFU-rapport. Norsk institutt for studier av innovasjon, forskning og utdanning. Oslo.

Saarikallio-Torp, Miia \& Wiers-Jenssen, Jannecke (eds.) (2010) Nordic students abroad. Student mobility patterns, student support systems and labour market outcomes. KELA, Research Department. Finland. Figur 1.4 p. 28.

Statistiska centralbyrån: Temarapport 2009:5 Hoegutbildades arbetsmarknad.

Støren, Liv Anne (2008). Høyere utdanning og arbeidsmarked - i Norge og Europa. Norsk rapportering fra EU-prosjektet "REFLEX". NIFU-rapport. Norsk institutt for studier av in-novasjon, forskning og utdanning. Oslo.

Støren, Liv Anne \& Aamodt, Per Olaf (2009). Overgang til arbeidslivet blant høyere utdannede - kvaliteten og nytten af utdanningen. Utdanning 2009. NIFU-rapport. Norsk institutt for studier av innovasjon, forskning og utdanning. Oslo.

The Finnish Higher Education Evaluation Council FINHEEC: Evaluation of the BolognaProcess Implementation in Finland. (2012).

Vibe, Nils; Brandt, Synnøve Skjersli \& Hovedhaugen, Elisabeth (2011) Underveis i videregående opplæring. Evaluering av Kunnskapsløftet. Underveisrapport fra prosjektet "Struktur, gjennemføring og kompetanseoppnåelse". NIFU-rapport. Norsk institutt for studier av innovasjon, forskning og utdanning. Oslo.

Wiers-Jenssen, Jannecke (2008). Studiemobilitet og arbeidsmarkedstilpasning. Nordisk Kandidatundersøkelse 2007 - landrapport fra Norge. NIFU-rapport. Norsk institutt for studier av innovasjon, forskning og utdanning. Oslo.

\section{Diverse Websites}

Koordinerede danske tilmelding: http://www.kot.dk/KOT/statistik hovedtal.html Koordinerede finske tilmelding: https://kotaplus.csc.fi/online/Etusivu.do?lng=en Koordinerede svenske tilmelding: http://www.vhs.se/sv/ \& https://www.studera.nu/studera/index.html

\section{Island}

http://statice.is/?PageID=1297\&src=/temp_en/Dialog/varval.asp?ma=SK004103\% $26 \mathrm{ti}=$ Students+by+level $\% 2 \mathrm{C}+$ type+of+study $\% 2 \mathrm{C}+$ degree $\% 2 \mathrm{C}+$ broad+field+of + edu ca-

tion+and+sex+1997\%2D2009++\%26path=../Database/skolamal/hsNemendur $/ \%$ 26lang=1\%26units=Number

http://statice.is/Statistics/Education/Universities

\section{Norge}

http://statbank.ssb.no//statistikkbanken

http://www.lanekassen.no/Hovedmeny/Om_Lanekassen/Statistikk/Elever-ogstudenter-totalt/Kostnadsnorm-og-stipend/

http://www.regjeringen.no/nb/dep/kd/dok/nouer/2000/nou-2000-

14/12/4.html?id=142931 


\section{Sverige}

http://www.ssd.scb.se/databaser/makro/Visavar.asp?yp=tansss\&xu=C9233001\&o mradekod=UF\&huvudtabell=StudiedeltagandeR\&omradetext=Utbildning $+o c h+$ fors kning\&tabelltext=Befolkning+16\%2D64+\%E5r+efter+k\%F6n\%2C+\%E5lder\%2C+t yp+av+studiedeltagande $\% 2 \mathrm{C}$

+utbildningsniv\%E5+och+studiemedelsutnyttjande+under+h\%F6stterminen $\% 2 \mathrm{E}+$ $\%$ C5r\&preskat $=0$ \&prodid $=$ UF0507\&deltabell $=+\&$ deltabellnamn=Befolkning $+16 \%$ 2D64+\%E5r+efter+k\% F6n $\% 2 \mathrm{C}+\%$ E5lder $\% 2 \mathrm{C}+$ typ+av+studiedeltagande $\% 2 \mathrm{C}+$ utbi ldningsniv\%E5+och+studiemedelsutnyttjan-

$\mathrm{de}+$ under+h\%F6stterminen\%2E+\%C5r\&innehall=StudiedeltagandeR\&starttid=19 93 \&stopptid=2008\&Fromwhere=M\&lang=1\&langdb=1

http://www.scb.se/statistik/_publikationer/UF0515_2012A01_BR_AM85BR1201.pdf

\section{Finland}

http://www.kela.fi/in/inter net/english.nsf/alias/kelasto_content\#Students http://www.helsinki.fi/teachereducation/step/information/qualifications/index.html 
Nordisk Ministerråd

Ved Stranden 18

DK-1061 København K

www.norden.org

\section{Højere uddannelse i Norden}

Hvert år udsender OECD publikationen: Education at a Glance. Denne rapport er et første forsøg på en særlig Nordic Education at a Glance. De nordiske lande klarer sig godt på en række indikatorer. Uddannelsesniveauet er ganske højt. Norden er god til at bryde den sociale arv. Udvekslingen af internationale studerende er stigende. Kvinderne i Norden ligger usædvanlig godt i international sammenhæng. Gennemførelsesprocenter og studietider ligger mere på det jævne. Selvom der er aktuel ledighed blandt højere uddannede i flere nordiske lande, kan der opstå mangler på længere sigt. Publikationen peger på behov for flere analyser af forskellene mellem de nordiske lande.

TemaNord 2013:512

ISBN 978-92-893-2480-9

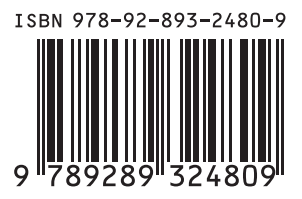

